\title{
Estudio relativo a los principios de la potestad sancionadora y a la tramitación del nuevo procedimiento sancionador común, a la vista de su regulación en las leyes $39 / 2015$ y 40/2015 y de la jurisprudencia reciente
}

\author{
Sonia Gavieiro González
}

DOI: https://doi.org/10.47623/ivap-rvap.110.2018.1.10

\begin{abstract}
Sumario: I. Introducción. - II. Análisis de los principios de la potestad sancionadora, a la luz de las Leyes 39/2015 y 40/2015, así como de la jurisprudencia reciente: 1 . El principio de legalidad y sus relaciones con el principio de irretroactividad y tipicidad. 2. El principio de responsabilidad en el procedimiento administrativo sancionador. 3. La proporcionalidad y su relación con otros principios de la potestad sancionadora. 4. La prescripción: ¿otro principio de la potestad sancionadora?-III. Estudio detallado de la tramitación del procedimiento sancionador administrativo común, atendiendo a las Leyes 39 y $40 / 2015$ y a la jurisprudencia reciente: 1 . Algunas cuestiones previas a la incoación de un procedimiento sancionador administrativo. 2. Principales aspectos en relación con la incoación del procedimiento administrativo sancionador: el «arrepentimiento", medidas provisionales y diversas cuestiones en relación con el acuerdo de inicio. 3. La ordenación e instrucción: distinción de funciones, la prueba, la propuesta de resolución y posibilidad de archivo del procedimiento administrativo común. 4. Principales aspectos durante la fase de finalización del procedimiento sancionador. 5. La tramitación simplificada en el procedimiento administrativo sancionador común. 6. Posibilidad de interponer recurso frente a la resolución finalizadora de un procedimiento sancionador administrativo.-IV. Conclusiones.
\end{abstract}

\section{Introducción}

El 2 de octubre de 2016 entraron en vigor la Ley 39/2015, de 1 de octubre, de Procedimiento Administrativo Común de las Administraciones Públicas (LPACAP) y la Ley 40/2015, de 1 de octubre, de Régimen Jurídico del Sector Público (LRJSP). En lo que respecta a la materia sancio- 
nadora (procedimiento, principios,...), desde entonces se aplican ambas normas: la primera de ellas, en relación con el procedimiento por aquello de centrarse en la relación de la Administración con la ciudadanía ( «ad extra») y la segunda, especialmente en lo que respecta a los principios a tener en cuenta, si bien debe destacarse que también se regulan cuestiones propias del procedimiento como es el caso de la abstención o recusación.

Estas dos normas procedimentales han conllevado no sólo la derogación de la Ley 30/1992, de 26 de noviembre, de Régimen Jurídico de las Administraciones Públicas y Procedimiento Administrativo Común (LRJPAC), sino también del Real Decreto 1398/1993, de 4 de agosto, por el que se aprueba el Reglamento del Procedimiento para el ejercicio de la Potestad Sancionadora (REPEPOS). Por ello, la remisión que las normas sectoriales, estatales y autonómicas, realicen en materia sancionadora a ellas deberá entenderse realizada a las actuales LPACAP y a la LRJSP (1).

La aplicación de ambas leyes desde el 2 de octubre de 2016 por parte del personal de las Administraciones Públicas hace posible el análisis crítico que realizaremos en el presente artículo; es decir, no sólo buscaremos destacar novedades, sino también identificar cuestiones problemáticas que se hayan podido detectar durante este último año. A este respecto, la disposición final $17^{\text {a }}$ de la LRJSP requiere dicha adaptación en el mismo plazo para las «normas estatales o autonómicas que sean incompatibles con lo previsto en esta Ley»; sería aplicable en el supuesto de alguna incompatibilidad con los principios del procedimiento sancionador o con el régimen de abstención/recusación. Sin embargo, el aplazamiento de la entrada en vigor por plazo de un año planteado por la disposición final 5. ${ }^{a}$ de la LPACAP (2) se refiere sólo a los procedimientos normativos y no a los sancionadores.

(1) Debe mencionarse en este punto la disposición adicional $1 .{ }^{a}$, apartado 2, de la LPACAP, la cual se refiere a la aplicación supletoria de esta ley en los procedimientos sancionadores incoados en materia tributaria, aduanera, social, de tráfico, seguridad vial y extranjería. Para una mayor profundidad, PLEITE GUADAMILLAS, Francisco, "El procedimiento administrativo poco común de la Ley 39/2015, de 1 de octubre», en Actualidad Administrativa núm. 1, 2017.

Debe apercibirse en este punto de que el Pleno del Tribunal Constitucional ha admitido mediante sendas Providencias de 19 de julio de 2016 los recursos de inconstitucionalidad formulados contra el artículo 1.2 de la LPACAP por la Generalitat y por el Gobierno de Canarias.

(2) Debemos decir que diversos autores han dudado de la constitucionalidad de esta disposición final, atendiendo a la posible invasión de ámbitos de decisión autonómicos, y tomando como referencia el dictamen del Consejo de Estado n. ${ }^{\circ}$ 275/2015, de 29 de abril de 2015, cuando se exige a toda norma su adaptación en el plazo de un año. Así, en CAMPOS ACUÑA, Concepción, Comentarios a la Ley 39/2015 de Procedimiento Administrativo Común de las Administraciones Públicas. Wolters Kluwer. Las Rozas, 2017, pág. 900. 


\section{Análisis de los principios de la potestad sancionadora, a la luz de las Leyes 39/2015 y 40/2015, así como de la jurisprudencia reciente}

Además de los principios generales (art. 3 LRJSP) y de los principios de intervención de las Administraciones (art. 4 LRJSP), cuando estemos ante un procedimiento sancionador administrativo, se respetarán específicamente aquellos reconocidos en el Capítulo III del Título Preliminar de la LRJSP. A su vez, en el supuesto de un procedimiento disciplinario, se cumplirán también los principios recogidos en el artículo 98.2 del Real Decreto Legislativo 5/2015, de 30 de octubre, por el que se aprueba el texto refundido del Estatuto Básico del Empleado Público (3) (eficacia, celeridad, economía procesal, pleno respeto a los derechos y garantías de defensa y debida separación entre la fase instructora y sancionadora).

Centrándonos en la potestad sancionadora común, es el Capítulo III delTítulo Preliminar de la citada LRJSP el que se refiere a sus principios. Asimismo, en el ámbito más concreto disciplinario, el artículo 94 del TREBEP recoge los mismos principios, con la especificidad de que entiende cumplido el de tipicidad si en el caso del personal laboral se reconoce esa falta en un convenio colectivo; no se califica la prescripción, ni la concurrencia de sanciones, recogidas en cambio en la LRJSP, como tales principios. Realicemos una breve referencia en este punto al artículo 25.3 de la LRJSP, que extiende la regulación de los principios de la potestad sancionadora del indicado Capítulo III a la potestad disciplinaria del personal al servicio de la Administración, "cualquiera que sea la naturaleza jurídica de la relación de empleo" (4). A su vez, siguiendo las sentencias del Tribunal Constitucional n. ${ }^{\circ}$ 18/1991, de 8 de junio, y 246/1991, de 19 de diciembre, los principios inspiradores del orden penal también son de aplicación al Derecho administrativo sancionador, si bien con ciertos matices, sólo en la medida en que sean compatibles con los procedimientos de naturaleza administrativa (5).

(3) En adelante, TREBEP.

(4) Atendiendo al tenor literal de dicho precepto («cualquiera que sea la naturaleza jurídica»), así como a la disposición final 17. ${ }^{\text {a }}$ de la LRJSP, consideramos no aplicable el artículo 1.2 de la Ley 2/1998, de 20 de febrero, de la Potestad Sancionadora de las Administraciones Públicas Vascas (LPS) que excluye, incluso, la aplicación de los principios de la potestad sancionadora a la disciplinaria. A este respecto, el artículo 8 del TREBEP incluye funcionariado de carrera e interino, personal laboral fijo, por tiempo indefinido o temporal, así como personal eventual, si bien existen dudas en relación con este último (de hecho, si contra el mismo cabe la sanción máxima que es el cese por parte de quien nombró a ese personal eventual, no tiene mucho sentido incoarle un procedimiento disciplinario).

(5) Para una mayor profundidad al respecto, recomendamos la lectura de PAREJO ALFONSO, Luciano, "Algunas reflexiones sobre la necesidad de la depuración del status de la sanción administrativa», en RGDA núm. 36, 2014. 
Ahora bien, en ningún caso se aplicarán estos principios (Cap. III del Título Preliminar de la LRJSP) a las personas relacionadas por la legislación de contratos del sector público (6) o por la legislación patrimonial de las Administraciones Públicas. Entendemos que se buscan excluir las penalidades en materia de contratos por su naturaleza convencional (pues son penalidades aceptadas voluntariamente por quien sea contratista, atendiendo a los principios de riesgo y ventura que asume), así como los contratos excluidos de la propia normativa sectorial (como son los de compraventa, donación, permuta, arrendamiento y demás negocios jurídicos análogos sobre bienes inmuebles, valores negociables y propiedades incorporales, los cuales se regularán por la normativa patrimonial(7)). Centrándonos en el objeto del presente artículo, la LRJSP regula actualmente los principios de la potestad sancionadora de forma similar a la anterior normativa de procedimiento administrativo (arts. 127-133 de la LRJPAC).

\section{El principio de legalidad y sus relaciones con el principio de irretroactividad y tipicidad}

En primer lugar, el principio de legalidad es objeto actualmente del artículo 25 de la LRJSP. Más en detalle, esta manifestación del artículo 9.3 de la Constitución tiene dos exigencias: por un lado, la infracción y la sanción deben estar reconocidas por una norma con rango de ley (8) y, por otro, se debe seguir el procedimiento previsto en la normativa (9). Esto incluye, a su vez, un doble mandato: uno material y absoluto (por el cual debe respetarse la definición cierta de la infracción...) y otro formal (relativo al rango de las normas). No se excluye el desarrollo reglamentario,

(6) En este mismo sentido, el artículo 1.2 de la LPS.

(7) Así lo establece el artículo 4.1.p) del Real Decreto Legislativo 3/2011, de 14 de noviembre, por el que se aprueba el texto refundido de la Ley de Contratos del Sector Público (hoy, art. 9 de la Ley 9/2017, de 8 de noviembre, de Contratos del Sector Público).

(8) Artículo 25.1 de la Constitución. Incluso, la disposición adicional segunda de la Ley 2/2016, de 7 de abril, de Instituciones Locales de Euskadi habilita a las ordenanzas locales para sustituir las sanciones pecuniarias por "trabajos de valor equivalente para la comunidad local, incluidas asistencias a sesiones formativas o participación en actividades cívicas, y proporcionadas a la gravedad de la infracción, cuando así lo acuerde el órgano sancionador", siempre previo consentimiento de la persona afectada y salvo que la ley sectorial impusiera su carácter obligatorio.

(9) Así lo indican no sólo el artículo 25.1 de la LRJSP, sino también el 63.2 de la LPACAP e, incluso, el 98.1 del TREBEP para el procedimiento disciplinario, y el 149.1 del Real Decreto Legislativo 781/1986, de 18 de abril, por el que se aprueba el texto refundido de las disposiciones legales vigentes en materia local. Podemos relacionar dichos preceptos con el artículo 103.1 de la Constitución también, de acuerdo con el cual, la Administración Pública actuará con sometimiento pleno a la ley y al Derecho. 
siempre que la ley fije los criterios mínimos de antijuridicidad que limiten las ordenanzas locales(10); así se salvaría la imposibilidad de aprobación de leyes por las Entidades Locales puesto que elTítulo XI de la Ley 7/1985, de 2 de abril, Reguladora de Bases del Régimen Local (LRBRL) fijaría dicho umbral mínimo.

Además, el ejercicio de la potestad sancionadora le corresponde a los órganos administrativos (instructor y resolutorio) que la tengan expresamente atribuida por una disposición de rango legal o reglamentario(11). Por lo tanto, no puede ejercerse por entidades de carácter jurídico-privado. Se trata de una separación funcional. Recordemos brevemente que la separación orgánica requerida en el ámbito administrativo es menos restrictiva que en el penal, no suponiendo un obstáculo que el órgano instructor esté sometido jerárquicamente al órgano encargado de resolver el procedimiento administrativo(12).

Este primer principio tiene su complemento en el de irretroactividad(13), hoy regulado en el artículo 26 de la LRJSP y antes de forma similar, en el 128 de la LRJPAC, puesto que la predeterminación normativa de infracciones y sanciones tiene una relación directa con la prohibición general de la aplicación retroactiva de las normas sancionadoras. En concreto, se aplicarán sólo las disposiciones sancionadoras vigentes en el momento de producirse los hechos que constituyan infracción administrativa (14).

Como ya sabemos, la única excepción es la retroactividad in bonus, cuando se favorezca a la persona inculpada; la mejora técnica en este caso reside en concretar el alcance de ésta, es decir, será posible dicha retroactividad "tanto en lo referido a la tipificación de la infracción como a la sanción y a sus plazos de prescripción, incluso respecto de las sanciones pendientes de cumplimiento al entrar en vigor la nueva disposición» (15). La jurisprudencia ha concretado el alcance del precepto citado, al establecer que la norma más favorable se aplicará «en bloque, no fragmentariamente", pues lo contrario supondría usurpar ta-

(10) En este sentido, podemos citar las sentencias del Tribunal Constitucional 132/2001, 16/2004 y 35/2004. A modo de ejemplo, las posibles infracciones en el caso de las Entidades Locales vienen delimitadas en los artículos 139 y 140 de la LRBRL; en este sentido, la "Guía Local», elaborada por la Administración de la Comunidad Autónoma de Euskadi, IVAP, 2016, pág. 372.

(11) Artículo 25.2 de la LRJSP.

(12) Destacamos en este punto el artículo 29.4 de la LPS, el cual acertadamente prevé que quien instruya «no tendrá ninguna dependencia funcional en lo referente al cumplimiento de su labor instructora y durante el tiempo que dure ésta».

(13) A este respecto, sentencias delTribunal Constitucional n. ${ }^{\circ}$ 196/1991, de 17 de octubre, y 95/1992, de 11 de junio.

(14) Artículo 26.1 de la LRJSP.

(15) Artículo 26.2 de la LRJSP.

R.V.A.P. núm. 110-I. Enero-Abril 2018. Págs. 315-357 ISSN: 0211-9560 
reas legislativas que no corresponden a los órganos judiciales (16). Atendiendo a cierta jurisprudencia, el límite temporal lo encontramos en el momento de emitirse sentencia por parte del órgano judicial contencioso-administrativo (17).

Otro principio relacionado con el de legalidad es el de tipicidad, hoy regulado en el artículo 27 de la LRJSP de forma muy similar a la anterior (art. 129 LRJPAC); en cuanto a la normativa autonómica, citaremos el artículo 13 de la Ley 2/1998 de la Potestad Sancionadora de las Administraciones Públicas Vascas (LPS). Atendiendo al mismo, constituyen infracciones administrativas las vulneraciones del ordenamiento jurídico previstas como tales por una ley, sin perjuicio de lo dispuesto para la Administración Local en el Título XI de la LRBRL. Las sanciones también estarán delimitadas por la ley (18). Anteriormente en este mismo apartado hemos tratado la doble garantía: la material (relativa al grado de certeza para definir las infracciones y sanciones) y la formal (en cuanto a exigir su tratamiento en una norma con rango de ley). Respecto a esta última, en el caso de las Entidades Locales se cita su tratamiento específico al posibilitárseles que realicen desarrollos reglamentarios que no contradigan leyes estatales o autonómicas (19). En cambio, se prohíben innovaciones mediante normas reglamentarias (20), de la misma forma que las calificadas como remisiones en

(16) Así se ha pronunciado el Tribunal Constitucional en Auto . $^{\circ} 471 / 1984$, de 24 de julio, y en sentencia n. ${ }^{\circ}$ 131/1986, de 29 de octubre, ambas resoluciones en su Fundamento de Derecho $2 .^{\circ}$. Recomendamos también la lectura de las SSTC n. ${ }^{\circ}$ 99/2000, de 10 de abril (especialmente, fundamentos jurídicos tercero a quinto) y $85 / 2006$, de 27 de marzo (fundamento jurídico cuarto). En este punto indicaremos que sentencias como las SSTS de 26 de febrero de 1991 o de 5 de junio de 2007 consideran normas neutras las de carácter procedimental, tales como las relativas a los plazos de caducidad; lo contrario sucede respecto a la prescripción, atendiendo a las SSTS de 28 de enero de 2009 o de 16 de enero de 2003

(17) En este sentido, SSTS de 24 de enero de 2006, recurso núm. 419/2002, y de 4 de noviembre de 2013, recurso núm. 251/2011. Incluso, sentencias como las de los Tribunales de Justicia de Canarias de Las Palmas de Gran Canaria y de Cataluña de 13 de octubre de 2010 y de 22 de diciembre de 2011, respectivamente, consideran aplicable la retroactividad in bonus cuando entra en vigor una norma durante el propio procedimiento judicial, lo cual no podemos evitar calificar como excesivo pues difícilmente el órgano administrativo podría aplicar esa nueva norma más favorable durante la tramitación de su procedimiento sancionador. En cualquier caso, para una mayor profundidad, GARCÍA URETA, Agustín, "Consideraciones sobre la incidencia de las Leyes 39 y 40/2015 en la Ley 2/1998, de la potestad sancionadora de las administraciones públicas de la Comunidad Autónoma del País Vasco", en RVAP núm. 107, 2017, págs. 145-146.

(18) Artículos 27.2 de la LRJSP y 14.1 de la LPS.

(19) STS de 10 de abril de 2014, recurso núm. 2094/2012.

(20) Atendiendo al tenor literal del artículo 27.3 de la LRJSP, las disposiciones reglamentarias de desarrollo podrán introducir especificaciones o graduaciones, para contribuir a la más correcta identificación o a la más precisa determinación de infracciones y/o sanciones, sin que dichas consideraciones puedan constituir «nuevas infracciones o sanciones, ni alterar la naturaleza límites de las que la Ley contempla». 
blanco, atendiendo a la sentencia del Tribunal Constitucional 132/2001, de 8 de junio, en el sentido de no tolerarse "la renuncia de la ley a todo encuadramiento normativo de la potestad tributaria local» (21). En este punto el Tribunal Constitucional en sentencia $n .^{\circ} 127 / 1990$, de 5 de julio, concreta los requisitos de dichas normas denominadas en blanco: la ley debe señalar la pena y el núcleo esencial de la prohibición, con certeza(22) y con posibilidad de conocimiento de la actuación castigada, con reenvío expreso y justificado en razón del bien jurídico protegido.

Otra manifestación del principio de tipicidad, sin duda, la encontramos en el artículo 27.4 de la LRJSP, en virtud del cual, se prohíbe la analogía para crear infracciones administrativas y para definir sanciones. Como indica el Tribunal Constitucional en sentencia n. ${ }^{\circ}$ 120/1996, de 8 de julio, la tipicidad, como complemento de la predeterminación normativa, impide que el órgano sancionador actúe frente a comportamientos que se sitúan fuera de las fronteras que demarcan la norma sancionadora puesto que la tipicidad es un derecho instrumental a través del cual se consigue la plena de las garantías constitucionales(23). Ahora bien, no podemos negar que cierto sector doctrinal defiende cierta analogía cuando se introduzcan reglas más favorables(24); sería el caso de la regla del actual artículo 21.7 del Código Penal (cualquier otra circunstancia atenuante «de análoga significación que las anteriores»).

\section{El principio de responsabilidad en el procedimiento administrativo sancionador}

Por otra parte, el artículo 28 de la LRJSP regula el principio de responsabilidad, si bien quizás es uno de los preceptos que trataremos en este epígrafe que presentan mayores novedades respecto a la anterior regula-

(21) Fundamento jurídico $5 .^{\circ}$

(22) En sentido muy similar de exigir la mayor precisión posible..., se expresa el artículo 4 de la LPS.

(23) Dicha cualificación como derecho fundamental la realiza la STC $n .{ }^{\circ} 7 / 1998$, de 13 de enero. Una manifestación de la importancia de la exactitud en la infracción tipificada la encontramos respecto a la actual sustitución de la licencia de apertura de una actividad por una declaración responsable o comunicación, como consecuencia de la transposición de la Directiva 2006/123CE. Reflexiona en este sentido ORDÓÑEZ SOLíS, David, "Licencias, sanciones y tasas bajo sospecha: las ordenanzas municipales y la Directiva de servicios» en El Consultor de los Ayuntamientos núm. 6, 2011, pág. 8. También TÁBOAS BENTANACHS, Manuel, "La proyección de la Directiva 2006/123/CE, del Parlamento Europeo y del Consejo, de 12 de diciembre de 2006, relativa a los servicios en el mercado interior, en los ámbitos urbanístico y medioambiental» en Cuadernos de Derecho Local núm. 23, 2010, pág. 77.

(24) CAMPOS ACUÑA, Concepción, Comentarios a la Ley 40/2015 de Régimen Jurídico del Sector Público. Wolters Kluwer. Las Rozas. 2017, pág. 155. 
ción. Relacionando el 28.1 de la LRJSP con el artículo 103.1 de la Constitución, según la sentencia del Tribunal Supremo de 30 de septiembre de 2011 (25), hoy podrán ser sancionadas por hechos constitutivos de infracción administrativa, además de las personas físicas y jurídicas (26), los grupos de afectados, las uniones y entidades sin personalidad jurídica y los patrimonios independientes o autónomos, siempre que se les reconozca capacidad de obrar por parte de una ley (27); para dicha sanción, deberán ser responsables a título de dolo o de culpa. En primer lugar, respecto al anterior artículo 130.1 de la LRJPAC, podemos observar que se han ampliado los sujetos responsables. En relación con el título de responsabilidad, además, hemos hablado de dolo o culpa. No cabe la simple inobservancia ahora puesto que ya la STS de 21 de enero de 2011 la interpretó en el sentido de requerir que existiera culpa concretada "en la falta de diligencia observada por la entidad recurrente» (28); en ese sentido, por lo tanto, deberán interpretarse las normas sectoriales (es el caso de salud o tráfico) y el artículo 3 de la LPS que reconocían esta última.

Ninguna referencia consta a la acción u omisión, con lo que podemos interpretar que sería posible la comisión por falta de actuación. Tampoco se distingue sobre el grado de autoría en el artículo 28.1 de la LRJSP; podemos completarlo, por ello, con el 9 de la LPS, el cual considera responsables no sólo a las personas que realicen el hecho, "por sí solas, conjuntamente o por medio de otra de la que se sirvan como instrumento» (29),

(25) Recurso núm. 566/2009.

(26) Recordemos que, en casos de autoría de persona jurídica, el juicio de culpabilidad se realizará en cuanto a las personas físicas que hayan formado su voluntad en la concreta actuación u omisión a sancionar (art. 9.3 LPS). Para más profundidad DÍEZ SASTRE, Silvia, "Culpa vs. llegalidad. De nuevo sobre el fundamento de la responsabilidad por acto administrativo" en REDA núm. 153, 2012, págs. 63-88.

(27) En otro caso, si una norma con rango legal no les reconoce capacidad de obrar, se estará a una responsabilidad personal de quien se encuentre detrás de esa entidad sin personalidad jurídica, ...

(28) STS de 21 de enero de 2011, recurso núm. 598/2008, fundamento jurídico 5.․ En relación con la "simple inobservancia», recomendamos LASAGABASTER HERRARTE, Iñaki, Ley de la Potestad Sancionadora. Comentario sistemático. Lete. Bilbao. 2006. Págs. 392-403.

(29) Artículo 9.1 de la LPS. Debemos completar dicho precepto con el artículo 28.3 de la LRJSP, en virtud del cual, cuando varias personas conjuntamente realicen una infracción, éstas responderán de forma solidaria, con carácter general; de manera que la Administración podrá ir contra cualquiera de ellas o contra todas. Es el caso de dos empresas que han realizado la misma infracción y comparten sede social y director general, aunque no sean un grupo empresarial, según STS de 1 de abril de 2016, recurso núm. 3691/2013, que cita la sentencia del TJUE de 28 de junio de 2005, asunto C-189/02.

Ahora bien, como novedad reseñable de este último precepto, si la sanción es pecuniaria y es posible su individualización, hoy la resolución final fijará dicha responsabilidad individual en función del grado de participación. Reseñamos aquí la importancia del principio de proporcionalidad (STS de 1 de abril de 2016, citada) y de la motivación en caso de imposibilidad de individualización (respecto a la importancia de ambos, STS de 13 de febrero de 2017, recurso n. ${ }^{\circ}$ 3676/2014, fundamento jurídico segundo, in fine). 
sino también a quienes cooperen y a quienes incumplan el deber impuesto por una ley, salvo que no se pueda demostrar la existencia de infracción o la autoría material de la persona respecto de la que el deber de prevención se ha impuesto(30). Por supuesto, además, tal y como habilita el artículo 10 de la LPS antes mencionada, las normas sectoriales podrán definir las personas responsables atendiendo a la naturaleza y finalidad del régimen sancionador de que se trate; a modo de ejemplo, la Ley 2/2006, de 30 de junio, de Suelo y Urbanismo de la Comunidad Autónoma Vasca se refiere en su artículos 225 y siguientes a quienes sean promotores/as de una obra, al personal técnico que la dirija en el caso de obras ilegalizables realizadas sin autorización, ...

En cualquier caso, se echa de menos una regulación concreta ante infracciones cometidas por personas incapacitadas o menores de edad (31); ahora bien, el artículo 28.4 de la LRJSP habilita de forma novedosa a las leyes reguladoras de los distintos regímenes sancionadores para que tipifiquen como infracción el incumplimiento de la obligación de prevenir la comisión de infracciones administrativas ante relaciones de dependencia o vinculación, incluyendo la posibilidad de que determinadas personas respondan del pago de sanciones pecuniarias impuestas a quienes de ellas dependan o estén vinculadas. La redacción nos genera posibles dudas puesto que no se especifica el tipo o grado de relación de afectividad requerida.

En todo caso, la Administración tiene la carga de la prueba y debe demostrar todos los elementos de hecho necesarios para poder imponer la sanción, siguiendo con el criterio del Tribunal Constitucional en sentencias de 11 de marzo de 1997 y de 22 de abril de 2004. En caso contrario, se estará a la presunción de no existencia de responsabilidad ad-

(30) Artículo 9.2 de la LPS; en similar sentido, la STS de 23 de febrero de 2011, recurso núm. 562/2008, que se refiere a autores/as, cómplices o encubridores/as de la acción u omisión. Atendiendo al artículo 5 de la misma LPS, no se sancionarán la conspiración, ni la proposición, provocación o la apología de la infracción. Lo contrario sobre inducción y encubrimiento viene establecido para el personal funcionarial y laboral por el artículo 93 del TREBEP. En este punto, recomendamos la reflexión realizada por REBOLLO PUIG, Manuel, "Responsabilidad de los autores de las infracciones y de los partícipes» en RVAP núm. Especial 99-100, 2014, págs. 2527-2546.

(31) Podemos alabar, en este punto, la claridad del artículo 6 de la LPS, al establecer una edad mínima de 14 años para responder administrativamente, en caso de falta de norma sectorial específica. Otras posibles excepciones fijadas en este último precepto son las previstas en el Código Penal (en concreto, el artículo 130 se refiere a la muerte, prescripción, cumplimiento de la sanción e indulto - las mismas causas de extinción de la responsabilidad disciplinaria vienen recocidas en el artículo 89.1 de la Ley 6/1989 de Función Pública Vasca-), además del error invencible sobre un elemento del tipo o sobre la ilicitud del hecho infractor y el error vencible cuando el dolo sea elemento integrante del tipo infractor aplicado. Únicamente citaremos en el presente trabajo que la posibilidad de indulto en estos casos viene regulada en los artículos 19 a 21 de la LPS. 
ministrativa (32) ya que la jurisprudencia impide que se admita en este ámbito sancionador la responsabilidad objetiva (33). En otras palabras, sólo puede imponerse una sanción tras una previa actividad probatoria sobre la que el órgano competente pueda fundamentar un juicio razonable de culpabilidad: probándolo y motivando los hechos constitutivos de la infracción, la participación en tales hechos, las circunstancias que constituyan criterio de graduación y la culpabilidad que justifica la imposición de la sanción. Por ello, debe destruirse la presunción de inocencia de la persona inculpada por medio de las pruebas que obren en el expediente administrativo(34). Son válidas al respecto tanto pruebas directas, como indirectas, siendo estas últimas aquellas que permiten de unos hechos probados directamente intuir que son ciertas también otras consecuencias con deducción lógica y precisa según las reglas del criterio humano (35).

Siguiendo los artículos 28.2 de la LRJSP y 12 de la LPS, se posibilita que las sanciones convivan con otras conductas negativas al prever que la responsabilidad administrativa por una infracción es compatible con la exigencia a la misma persona de la reposición de la situación alterada a su estado originario, así como con la indemnización por los daños y perjuicios causados. Esta última será determinada y exigida por el órgano a quien le corresponda el ejercicio de la potestad sancionadora; de manera que, cuando no se le abone a la Administración en el plazo concedido al respecto según la cuantía requerida, ésta deberá seguir el procedimiento de apremio previsto en el artículo 101 de la LPACAP, tal y como analizaremos en el segundo epígrafe del presente artículo al tratar del artículo 90.4 de la LPACAP.

(32) Artículo 53.2.b) de la LRJSP.

(33) STS de 18 de septiembre de 2008 (recurso núm. 317/2004), en línea con la STS de 29 de marzo de 2004 (recurso núm. 2217/2002, fundamento jurídico 3. ${ }^{\circ}$ ) y con la STC 76/1990, de 26 de abril.

(34) STS de 21 de enero de 2011, antes citada. Asimismo, de acuerdo con la STS de 23 de febrero de 2011 también mencionada, debe probarse que esa persona es la autora, cómplice o encubridora de una acción u omisión que supone la conducta ilícita que le es imputable, sin que concurran circunstancias que alteren su capacidad de obrar, de manera que debe haber actuado con conciencia y voluntariedad, bien a título intencional, bien a título culposo. De hecho, se considera que existe voluntariedad en quien abre una actividad al público, sabiendo que no puede hacerlo sin su tramitación (STS de 30 de septiembre de 2011, también antedicha).

(35) A modo de ejemplo, podemos saber con certeza que un establecimiento está abierto un día concreto, también que no se ha presentado ante la Administración competente la comunicación previa que habilita para su apertura; de todo ello podemos deducir que abrió el establecimiento quien está trabajando ese día y es identificado/a en el acta de inspección. 


\section{La proporcionalidad y su relación con otros principios de la potestad sancionadora}

Según jurisprudencia del Tribunal Supremo(36), es primordial respetar el principio de proporcionalidad en la imposición e individualización de la sanción. Éste, además, viene desarrollado hoy en el artículo 29 de la LRJSP, antes 131 LRJPAC. Comenzando por las novedades actuales, diremos que se deberá observar la debida idoneidad y necesidad de la sanción a imponer y su adecuación a la gravedad del hecho constitutivo de la infracción; de manera que la graduación de la sanción considerará y justificará la existencia, en su caso, de los siguientes criterios(37): el grado de culpabilidad, intencionalidad(38), continuidad o persistencia en la conducta infractora (39), naturaleza de los perjuicios causados y/o reincidencia (40). De hecho, cuando se justifique la debida adecuación entre la sanción con la gravedad del hecho constitutivo de la infracción y las circunstancias concurrentes, el órgano competente para resolver podrá imponer la sanción en el grado inferior; según jurisprudencia pacífica, la sanción pecuniaria debe ser adaptada a la gravedad del hecho por el que se acuerda su imposición(41). En estos supuestos de multas económicas, además, deberá preverse que la comisión de la infracción no resulte más beneficiosa para la persona infractora que el cumpli-

(36) Así, STS de 1 de abril de 2016, ya mencionada; así como la de 25 de febrero de 2009, recurso núm. 232/2006, la cual requiere una ponderación individualizada de todas las sanciones a imponer.

(37) La STS de 30 de septiembre de 2011, citada anteriormente, considera cumplido el principio de proporcionalidad cuando se impone la sanción en su cuantía máxima tras haber justificado que concurren todos los criterios que seguidamente citamos y que indica el artículo 29.3 de la LRJSP.

(38) Dicha intencionalidad está en línea con la culpa o dolo como elemento fundamental del Derecho administrativo sancionador. De hecho, según reciente STS de 3 de abril de 2017, recurso núm. 3230/2014, en la intencionalidad encaja la actitud de persistencia en la infracción; sería el caso de la continuación de las emisiones contaminantes hasta la clausura administrativa forzosa de una actividad. Cierto sector doctrinal (CHAVES, ...) considera dicha intencionalidad un prius, mientras que califica de posterius la persistencia.

(39) La STS de 25 de febrero de 2009, recurso núm. 232/2006, ha considerado la existencia de continuidad ante un "conjunto de actuaciones que suponen una continuada actuación por parte de la empresa que en su conjunto acreditan el incumplimiento de las resoluciones adoptadas», justificándose por ello una sanción del $33 \%$ de la cuantía máxima posible.

(40) Se valora positivamente que se aclare con la LRJSP que estamos ante una reincidencia cuando se cometan en un año más de una infracción de la misma naturaleza, una vez declarada esa previa mediante resolución firme en vía administrativa; es decir, contra la que no quepa recurso administrativo. Esta definición de reincidencia proviene de jurisprudencia consolidada, tal como las SSTS de 24 de octubre de 2000 , de 11 de marzo de 2003 o de 30 de septiembre de 2011 . En concreto, atendiendo a esta primera resolución judicial citada, recurso núm 4553/1996, si se recurre esa sanción en vía contenciosa y posteriormente se incurre en la misma infracción, se considerará la reincidencia en el siguiente procedimiento sancionador.

(41) Art. 29.4 de la LRJSP. Así se observa, en la reciente STS de 9 de marzo de 2017, recurso núm. 4115/2014; o, incluso, en sentencias del orden penal como la de la Audiencia Provincial de 5 de marzo de 2011, recurso núm. 8/2010. 
miento de las normas, lo cual habilita para el decomiso siempre que habilite al respecto la normativa sectorial (42) (en otro caso, el beneficio obtenido con la infracción podrá tenerse en cuenta para la determinación de la sanción de multa u otras sustancialmente iguales (43)). Ahora bien, en ningún caso, podrán implicar las sanciones, directa o subsidiariamente, privación de libertad (44).

Otra de las novedades de este precepto (art. 29 LRJSP) se refiere a la definición de infracción continuada, elevando a rango legal la antes prevista en el artículo 4.6 del REPEPOS. En todo caso, dicho concepto ha sido desarrollado por la jurisprudencia (45), atendiendo a la cual, se entiende que se exige una pluralidad de acciones $u$ omisiones que infrinjan el mismo o semejantes preceptos administrativos en ejecución de un plan preconcebido o aprovechando idéntica ocasión. Matizaremos que el plazo de prescripción comienza a computar desde la última de esas infracciones continuadas, a pesar de que ciertas resoluciones judiciales anteriores concluyeran previamente que no prescribía ninguna hasta «en tanto no prescriba la más grave» (46).

Por su parte, en el artículo 29.5 de la LRJSP se eleva al rango legal la anterior regla del concurso medial (art. 4.4 REPEPOS). De acuerdo a la misma, cuando de la comisión de una infracción derive la comisión de otra u otras, se deberá imponer la sanción correspondiente a la infracción más grave cometida; por lo tanto, consideramos que ya no se aplicará la norma del artículo 17.2 de la LPS, que preveía la imposición de "las sanciones menos graves de las establecidas para cada infracción» (47).

(42) Art. 29.2 de la LRJSP, en relación con el 11.3 de la LPS.

(43) Art. 14.9 de la LPS. A modo de ejemplo, en lo que respecta al concepto de "volumen de negocios" previsto en la normativa de defensa de la competencia, conviene la lectura de la STS de 29 de enero de 2015, recurso núm. 2872/2013, especialmente fundamentos jurídicos quinto a décimo.

En este punto cabe mencionar la STS de 25 de febrero de 2009 nuevamente, la cual concluye que lógicamente existe beneficio cuando se realiza la actividad clausurada «pues la empresa no se habría expuesto o arriesgado a desobedecer la orden de paralización que le había sido dirigida si no es porque consideraba el incumplimiento más beneficioso para sus intereses que el acatamiento".

(44) Art. 29.1 de la LRJSP.

(45) A modo de ejemplo, STS de 30 de septiembre de 2008, recurso núm. 2305/2007, a pesar de circunscribirse al ámbito penal. En sentido similar, tenemos también la STS de 2 de noviembre de 2015, recurso núm. 1523/2013, la cual, citando la STJUE de 7 de enero de 2004, Aalborg Portland A/S, As. C-204/00, define una infracción continuada como "una serie de actos distintos separados pero que se suceden en el tiempo", en este caso, en materia de defensa de la competencia y "siempre que se inscriban en un plan conjunto debido a su objeto idéntico».

(46) STS de 3 de octubre de 2005, recurso núm. 1432/2002.

(47) Atendiendo a la derogación de toda norma contraria a la LRJSP, según la disposición derogatoria única de la propia LRJSP, y, especialmente, al apartado primero de la disposición final $14 .^{\text {a de la }}$ LRJSP que define estas cuestiones de carácter básico. 
Otra consecuencia distinta tendrá la comisión de dos infracciones con dos hechos distintos; en cuyo caso se impondrán todas las sanciones correspondientes a las diversas infracciones, de acuerdo con el artículo 17.1 de la misma LPS. También obtenemos otra consecuencia diferente ante un concurso de normas, cuyas reglas echamos de menos en la LRJSP; ante los hechos susceptibles con arreglo a dos o más preceptos tipificadores, se atenderá a las reglas descritas en el artículo 16 de la LPS citada, siempre que se cubra "la totalidad del significado antijurídico del hecho": preferencia de la norma especial respecto a la general, precepto subsidiario a aplicar sólo en defecto del principal, artículo más amplio o complejo absorberá al resto y, finalmente, en defecto de todos los criterios anteriores, se estará a la norma que imponga la sanción más grave.

Por otra parte, el actual artículo 31 de la LRJSP regula la concurrencia de sanciones o, en otras palabras, el principio de non bis in idem(48); de manera que no podrán sancionarse los hechos que lo hayan sido penal o administrativamente en los casos en que se aprecie identidad del sujeto, hecho y fundamento (49). Es la garantía material de este principio. Sin embargo, de este artículo 31.1 deducimos que hoy se ha suprimido la vertiente procedimental de este principio(50), en virtud del cual, se debería suspender nuestro procedimiento sancionador mientras se estuviera tramitando esa otra infracción. Ahora bien, cierto sector doctrinal considera aplicable a día de hoy la preferencia de un procedimiento penal con suspensión del sancionador administrativo, siguiendo la sentencia del Tribunal Supremo de 19 de abril de 1999 (51). Una posible solución a esta problemática podría residir en notificar al Ministerio Fiscal cuando se estime que los hechos también pudieran ser constitutivos de ilícito penal, con carácter previo a incoar el procedimiento sancionador administrativo (lo cual se haría tras recibir la notificación correspondiente de dicho Ministerio Fiscal en sentido negativo).

Ahora bien, no podemos olvidar la sentencia del Tribunal Constitucional 177/1999, de 11 de octubre. De conformidad con la misma, en el

(48) Para una mayor profundidad respecto a este principio, CUBERO MARCOS, José Ignacio, EI principio non bis in idem en la Ley vasca de la potestad sancionadora, IVAP. Oñati, 2010.

(49) Esta identidad de fundamento viene definida en el artículo 18.2 de la LPS.

(50) Esta vertiente procedimental venía reconocida en el artículo 7, apartados 1 y 2, del REPEPOS, e, incluso, la encontramos a día de hoy en los artículos 25 a 27 de la LPS, además de en normas sectoriales como el artículo 94.3 del TREBEP o el 56 del Real Decreto Legislativo 7/2015 por el que se aprueba el texto refundido de la Ley de Suelo y Rehabilitación Urbana.

(51) Así, en CAMPOS ACUÑA, Concepción, Comentarios a la Ley 40/2015..., op. cit., pág. 173. Para un análisis más profundo respecto al Derecho penal y el sancionador administrativo, recomendamos ALARCÓN SOTOMAYOR, Lucía, "Los confines de las sanciones: en busca de la frontera entre el Derecho penal y Derecho administrativo sancionador» en RAP núm. 195, 2014, págs. 135-167. 
supuesto de que se hubiera impuesto una sanción administrativa y con posterioridad se considerase la existencia de un delito penal, dicho Tribunal considera que no cabe incoar procedimiento penal puesto que "la interdicción del bis in idem no puede depender del orden de preferencia que normativamente se hubiese establecido entre los poderes constitucionalmente legitimados para el ejercicio del derecho punitivo y sancionador del Estado, ni menos aún de la eventual inobservancia, por la Administración sancionadora, de la legalidad aplicable, lo que significa que la preferencia de la jurisdicción penal sobre la potestad administrativa sancionadora ha de ser entendida como una garantía del ciudadano, complementaria de su derecho a no ser sancionado dos veces por unos mismos hechos"(52). De ello se concluye que "irrogada una sanción, sea ésta de índole penal o administrativa, no cabe, sin vulnerar el mencionado derecho fundamental, superponer o adicionar otra distinta, siempre que concurran las tan repetidas identidades de sujeto, hechos y fundamento" (53). Por su parte, concluyendo la inexistencia de vulneración del principio de non bis idem, recomendamos la lectura de la sentencia del mismo órgano 2/2003, de 16 de enero, la cual motiva dicha conclusión en que «no ha habido reiteración sancionadora (bis), ni tampoco la lesión del derecho a no ser sometido a un nuevo procedimiento punitivo por los mismos hechos (art. 24.2 en relación con el art. 25.1 CE), ya que el procedimiento administrativo sustanciado no es equiparable a un proceso penal a los efectos de este derecho fundamental» (54).

Otra novedad respecto a este principio la encontramos en el artículo 31.2 de la LRJSP, en virtud del cual, de forma similar al artículo 26 de la LPS, cuando un órgano de la Unión Europea hubiera impuesto una sanción por los mismos hechos, el órgano competente para resolver el procedimiento sancionador actual deberá tenerlo en cuenta a efectos de graduar la sanción que pudiera imponerse, todo ello aunque no concurra la identidad de sujeto y fundamento; incluso, podría llegar a minorarla, sin perjuicio de declarar la comisión de la infracción. No olvidemos, para finalizar con dicho principio, que el artículo 63.3 de la LPACAP limita la posibilidad de que estén pendientes varios procedimientos frente a la misma persona por el mismo tipo infractor, si bien dicho precepto será analizado en el siguiente epígrafe del presente artículo.

(52) FJ $3 .^{\circ}$ de la STC 177/1999 antes citada.

(53) FJ $4 .^{\circ}$ de la misma STC 177/1999.

(54) FJ $11 .^{\circ}$ de dicha STC 2/2003. 


\section{La prescripción: ¿otro principio de la potestad sancionadora?}

Si bien no cabe considerar la prescripción como otro principio de la potestad sancionadora, ésta viene regulada en el mismo Capítulo III del Título Preliminar de la LRJSP (art. 30), en sentido similar a los anteriores artículos 132 de la LRJPAC y 7 del REPEPOS. La novedad la observamos en la forma de cómputo de la prescripción de infracciones respecto al procedimiento sancionador común: se mantiene el cómputo "desde el día en que la infracción se hubiera cometido" (55), siendo novedosa la previsión para el caso de las infracciones continuadas o permanentes, la cual proviene de la jurisprudencia (56). Se mantiene la interrupción de la prescripción con la iniciación de un procedimiento administrativo de naturaleza sancionadora, siempre que se realice con conocimiento de la persona interesada(57). Ahora bien, se reinicia el cómputo del plazo de prescripción si el expediente sancionador estuviera paralizado durante más de un mes por causa no imputable a quien sea presuntamente responsable; añade el artículo 22.3 de la LPS acertadamente que también se reiniciará dicho cómputo desde el día siguiente a aquél en que termine el procedimiento sin declaración de responsabilidad.

En cuanto al plazo de prescripción de las sanciones, se mantiene su cómputo desde el día siguiente a aquel en que sea ejecutable la resolución por la que se impone dicha sanción o haya transcurrido el plazo para recurrirla (58). Como sabemos, interrumpirá el cómputo de la prescripción la incoación del procedimiento de ejecución, siempre que se realice con conocimiento de la persona interesada nuevamente; reiniciándose el mismo si dicho procedimiento se paraliza durante más de un mes por causa no imputable al infractor(59). La regla novedosa en este caso la encontramos respecto al cómputo durante la sustanciación del recurso de

(55) Arts. 30.2 de la LRJSP. Por el contrario, el art. 22.2 de la LPS se refiere al día siguiente de la comisión.

(56) A modo de ejemplo, STS de 30 de septiembre de 2008, recurso núm. 2305/2007 (aunque sea del ámbito penal); o SAN de 6 de noviembre de 2009, recurso núm. 524/2007.

(57) Artículo 30.2 de la LRJSP y, en el mismo sentido, art. 97.2 del TREBEP. Deducimos del tenor literal del citado artículo 30.2 que un procedimiento iniciado sin conocimiento de la persona presuntamente responsable no interrumpe el plazo de prescripción de la infracción.

(58) Salvo esa última coletilla relativa a "haya transcurrido...", el artículo 22.4 de la LPS es del mismo tenor que el del artículo 30.3 de la LRJSP.

(59) Art. 30.3 de la LRJSP. En este punto, una pequeña pista práctica nos la facilita el artículo 22.5 de la LPS: la realización de cualquier actuación encaminada al logro de la finalidad del procedimiento de ejecución y razonablemente proporcional a dicha finalidad impedirá considerar paralizado el procedimiento, siempre que la indicada actuación se acuerde por el órgano competente y se encuentre debidamente documentada su realización. 
alzada; de manera que en tal supuesto el plazo de prescripción de la sanción comenzará a contarse desde el día siguiente a aquel en que finalice el plazo legalmente previsto para la resolución de dicho recurso; por lo tanto, se considera superada la jurisprudencia en función de la cual las sanciones recurridas en alzada no prescribían (60).

\section{Estudio detallado de la tramitación del procedimiento sancionador administrativo común, atendiendo a las Leyes 39 y 40/2015 y a la jurisprudencia reciente}

Analizaremos en este apartado los principales trámites del nuevo procedimiento sancionador común, para lo cual, no sólo acudiremos a la lectura de las actuales normas de procedimiento comparándolas con la anteriormente vigente LRJPAC, sino también a la jurisprudencia reciente. Como punto previo, atendiendo al artículo 1.2 de la LPACAP, debe tenerse en cuenta que una ley sectorial puede incluir "trámites adicionales o distintos a los contemplados en esta ley", siempre que resulte eficaz, proporcionado y necesario para la consecución de los fines propios de ese procedimiento y siempre de manera motivada(61). A su vez, este mismo precepto prevé que mediante una norma reglamentaria se establezcan otras especialidades relativas a órganos competentes, plazos, formas de iniciación y terminación o informes a recabar. Por tanto, atendiendo a estas dos opciones, no resulta difícil imaginar que se amplían las opciones de desdibujar el procedimiento administrativo común regulado en la LPACAP, si bien debe recordarse que en el caso de trámites adicionales a incluir por ley se exige que los mismos resulten eficaces, proporcionados y necesarios (bajo control del Tribunal Constitucional), así como la exigencia de que el reglamento se limite a los aspectos aquí indicados (especialidades en cuanto a plazos,...).

(60) Así, entre otras, la STS de 22 de septiembre de 2008, recurso núm. 69/2005, o la STS de 15 de febrero de 2013, recurso núm. 3378/2008, además de la STC n. ${ }^{\circ} 37 / 2012$, de 19 de marzo.

De hecho, a día de hoy ya se ha dictado la primera sentencia que aplica este art. 30.3 de la LRJSP, en relación con el principio de retroactividad in bonus; es la sentencia del Juzgado de lo ContenciosoAdministrativo n. ${ }^{\circ} 1$ de Ourense de 10 de marzo de 2017, que considera prescrita una sanción al haber transcurrido más de dos años hasta la resolución expresa del recurso de alzada interpuesto sin haberse ejecutado dicha sanción.

(61) En caso de optarse por esta opción, debemos recordar que este tipo de procedimientos regulados en leyes especiales por razón de la materia se regirán, respecto a éstos, por lo dispuesto en dichas leyes sectoriales. Asimismo, las remisiones que estas normas sectoriales realicen a la normativa de procedimiento administrativo común antes vigente, se considerarán realizadas a las actuales LPACAP y LRJSP; de manera que estas últimas deberán cumplirse durante la tramitación de expedientes sancionadores en dichas materias (urbanístico, medioambiental, ...). Así, PENSADO SEIJAS, Alberto, "Estudio sobre las novedades de las Leyes 39/2015 y 40/2015 en el ámbito urbanístico", en El consultor urbanístico on line, 2016, pág. 7. 
En cualquier caso, la tramitación del procedimiento es imprescindible puesto que el artículo 63.2 de la LPACAP prohíbe imponer una sanción sin la indicada tramitación. Por ello, puede decirse que este precepto busca dar cumplimiento a la exigencia del artículo 105.c) de la Constitución de que la ley regule el procedimiento para producir los actos administrativos, garantizando la audiencia a la persona interesada cuando proceda. Puede llamar la atención que el artículo 85 de la LPACAP permita luego prescindir del procedimiento cuando, una vez iniciado el mismo, la persona infractora reconozca su responsabilidad. Debemos concluir que en ese supuesto también existiría un procedimiento, el cual consistiría como mínimo en la fase de incoación con audiencia a la persona infractora y en la finalización aplicando directamente la sanción sin trámite adicional alguno, como veremos al tratar este último precepto.

\section{Algunas cuestiones previas a la incoación de un procedimiento sancionador administrativo}

En primer lugar, debe tenerse en cuenta que el artículo 55 de la LPACAP continúa la regulación del artículo 12.1 del REPEPOS, al prever la posibilidad de realizar actuaciones previas con anterioridad al inicio de un procedimiento sancionador. La finalidad de las mismas, según el apartado segundo de dicho precepto, será conocer, con la mayor precisión posible, los hechos susceptibles de motivar su incoación (si han tenido lugar hechos susceptibles de ser considerados infracción administrativa o no...), la identificación de quien/es pudiera/n resultar responsable/s y las circunstancias relevantes que pudieran concurrir (conociendo la gravedad de los daños para tipificar la infracción, en su caso,...). Un ejemplo clásico podemos encontrarlo en la necesaria inspección para comprobar los hechos y resto de aspectos indicados, tras la presentación de una denuncia por parte de una tercera persona. Ahora bien, estas actuaciones previas deben limitarse a apreciar preliminarmente los aspectos indicados con el fin de, "entre otras cosas, evitar la incoación de expedientes que a la postre se demuestren innecesarios, con la natural perturbación para el administrado" (62), todo ello en aras a evitar pre-decidir permitiendo a la instrucción realizar sus funciones.

\footnotetext{
(62) Así se expresa la sentencia de la Sección $5 .^{a}$ de la Sala de lo Contencioso-Administrativo del Tribunal Superior de Justicia de Cataluña de 7 de marzo de 2014, además de la de la misma sala y órgano del Tribunal Superior de Justicia de Andalucía de Málaga de 31 de enero de 2014. A su vez, el Fundamente Jurídico $2 .^{\circ}$ de la primera resolución judicial citada requiere que se realicen actuaciones necesarias, no considerando como tales la obtención de documentación de la que esa Administración ya disponía.
} 
Estas actuaciones previas, que tendrán valor probatorio (63) y por ello deberán figurar en el expediente como antecedentes (64), serán realizadas por los órganos que tengan atribuidas las funciones de investigación, averiguación e inspección en la materia concreta (extranjería,...). En defecto de ello, lo cual es muy habitual que suceda en Administraciones no ordenadas jerárquicamente como un Ayuntamiento, las realizarán quienes determine el órgano competente para iniciar o resolver el procedimiento sancionador ante el que nos encontramos.

En cuanto al elemento temporal, con carácter general no existe plazo mínimo ni máximo para efectuar dichas actuaciones (65); ahora bien, obviamente deben evitarse dilaciones injustificadas o una "prolongación artificial del plazo de resolución» en palabras del Tribunal Supremo en sentencia de 27 de febrero de 2003 (66), y adoptarse resolución expresa incoando el expediente sancionador u ordenando el archivo de las actuaciones (siguiendo las conclusiones emitidas en sentencia del Tribunal Superior de Justicia de Castilla y León de 27 de febrero de 1999). A este respecto, debe tenerse en cuenta que las actuaciones previas no interrumpen el plazo de prescripción, atendiendo a la sentencia del Tribunal Supremo de 20 de octubre de 1993; si bien se han previsto excepciones en sentencias como la delTribunal Supremo de 26 de noviembre de 1996 al haberse realizado la actuación previa con conocimiento de la persona interesada (67). Incluso, en caso de una excesiva dilación, algún órgano judicial como la Audiencia Nacional en sentencias de 17 de octubre de 2007 o de 19 de noviembre de 2008 (68), han considerado caducado el procedimiento sancionador por considerarse que con ello se han utilizado las ac-

(63) STS de 6 de mayo de 2011, recurso núm. 607/2008.

(64) En este sentido, tenemos las sentencias del Tribunal Supremo de 26 de octubre de 1973, 22 de febrero de 1985 o de 26 de mayo de 1987. Más en concreto, la sentencia del Tribunal Superior de Justicia de Madrid de 22 de diciembre de 2015, en su Fundamento Jurídico 2. ${ }^{\circ}$, negaron que las diligencias previas sean actos de incoación «de oficio de los procedimientos administrativos en general»; es decir son antecedentes, pero no producen los efectos jurídicos materiales de un acuerdo de iniciación.

(65) En cualquier caso, la norma sectorial puede establecer algún plazo concreto al respecto. Así sucede con el artículo 24.5 de la Ley 28/205 para la defensa de la calidad alimentaria, el cual prevé la caducidad de la acción cuando transcurra más de un año sin incoar el procedimiento sancionador desde que la Administración conoció la existencia de la infracción y finalizó las diligencias para el esclarecimiento de los hechos; mencionemos que este precepto ha sido recurrido de inconstitucionalidad por la Generalitat y por el Gobierno vasco, si bien en este último caso se ha creado una Comisión Bilateral de Cooperación Administrativa para "resolver las discrepancias» (B.O.P.V. de 25 de noviembre de 2015).

(66) Recurso núm. 8747/1997.

(67) En el supuesto tratado en dicha resolución judicial se citó «a declarar al patrón del buque en ese caso concreto de infracción por pesca fuera de los caladeros nacionales" (STS de 26 de noviembre de 1996, Fundamento Jurídico $1 .^{\circ}$ \%.

(68) Recurso núm. 90/2008, Fundamento Jurídico 3.․ 
tuaciones previas de forma fraudulenta con el fin de burlar el plazo de caducidad (69).

Por otra parte, el artículo 56.2 de la LPACAP también permite adoptar de forma motivada medidas provisionales antes de incoar el procedimiento; esta posibilidad venía reconocida con la anterior regulación del artículo 72 de la LRJPAC «en los supuestos previstos expresamente por una norma de rango de Ley»(70). No se requiere audiencia previa para dicha adopción (71). En concreto, los requisitos para poder adoptarlas son que estemos ante un caso de urgencia inaplazable(72), que se busquen proteger provisionalmente los intereses implicados, que las medidas propuestas sean necesarias y proporcionadas, así como que no se causen perjuicios de imposible o difícil reparación a las personas interesadas ni supongan violación de derechos amparados por las leyes(73). En este punto, podemos citar algunos ejemplos de medidas cautelares descritos en el apartado tercero del mismo precepto, siempre en los términos previstos en la Ley 1/2000, de 7 de enero, de Enjuiciamiento Civil (suspensión temporal de actividades,...).

Este tipo de medidas pueden ser confirmadas, modificadas o levantadas en el acuerdo de incoación del procedimiento (74); de manera que este último debe adoptarse en un plazo máximo de quince días hábiles (75) tras la adopción de las indicadas medidas. En este mismo sentido, entenderemos el artículo 64.2.e) de la LPACAP, que exige que el acuerdo de incoación del procedimiento se pronuncie sobre las medidas provisio-

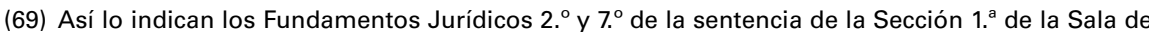
lo Contencioso-Administrativo de la Audiencia Nacional de 17 de octubre de 2007, en un supuesto en el que se mantuvo la solicitud de información abierta durante más de once meses sin realizar una actuación: "Nos hallamos ante un supuesto de Fraude de Ley, por cuanto se pretende burlar la aplicación del Art. 42.2 de la Ley 30/1992 usando la solicitud de información previa para, con ella, evitar la caducidad del expediente».

(70) Artículo 72.2 LRJPAC, según redacción tras Ley 4/1999, de 13 de enero, de modificación de la LRJPAC.

(71) MARINA JALVO, Belén, "Las medidas provisionales administrativas. Novedades incorporadas por el artículo 56 de la Ley 39/2015, de 1 de octubre, de Procedimiento Administrativo Común de las Administraciones Públicas», en RVAP núm. 109, 2017, págs. 173-174.

Recomendamos, para una mayor profundidad, MESEGUER YEBRA, Joaquín, Las medidas provisionales en vía administrativa. Bosh. Barcelona, 2000, págs. 59 y ss.

(72) Cierto sector doctrinal concede especial relevancia a este calificativo de «inaplazable» requerido para la urgencia. Es el caso de MARINA JALVO, Belén, "Las medidas provisionales administrativas...", op. cit., págs. 171-172.

(73) Nos referimos al artículo 56.4 de la LPACAP en el caso de este último requisito.

(74) El artículo 56.2 de la LPACAP establece la posibilidad de recurrir dicho acuerdo de incoación del procedimiento sancionador, pudiendo introducirse en el mismo escrito argumentaciones relativas a las medidas provisionales adoptadas. Entendemos que el motivo reside en considerarlo un acto de trámite cualificado (art. 112.1 LPACAP).

(75) El motivo de considerarlos hábiles reside en el artículo 30.1 de la LPACAP. 
nales. Al prever un plazo máximo de incoación del procedimiento sancionador, la LPACAP introduce una salvaguarda puesto que, si ese acuerdo no se adopta en el plazo indicado o si no se pronuncia en relación a las medidas provisionales adoptadas, éstas quedarán sin efecto y dejarán de utilizarse (por ejemplo, se devolverá la fianza solicitada, ...).

\section{Principales aspectos en relación con la incoación del procedimiento administrativo sancionador: acuerdo de inicio, el "arrepentimiento", y diversas cuestiones en relación con el acuerdo de inicio}

De conformidad con el artículo 63.1 de la LPACAP, los procedimientos de naturaleza sancionadora se inician siempre de oficio por acuerdo del órgano competente, atribuyéndose la competencia por parte de las normas reguladoras del procedimiento correspondiente. En el caso de un Ayuntamiento de régimen común, se atendería a los artículos 21 y 22 de la Ley 7/1985, de 2 de abril, Reguladora de Bases del Régimen Local (LR$B R L)$. Debe tenerse en cuenta que, si bien el acuerdo de incoación será del órgano competente para ello, puede caber cualquiera de las opciones de iniciación de oficio previstas en los artículos 58 a 62 de la LPACAP: por su propia iniciativa (art. 59 LPACAP), como consecuencia de una orden emitida por un órgano administrativo superior jerárquico suyo (art. 60 LPACAP(76)), petición razonada pero no vinculante formulada por cualquier órgano que no tenga competencia para su incoación (art. 61 LPACAP) o previa denuncia de cualquier persona (art. 62 LPACAP).

En este punto debe destacarse una de las novedades de la LPACAP: el arrepentimiento. De conformidad con el artículo 62.4 de la LPACAP, cuando quien presenta la denuncia haya participado en una infracción y existan otras personas infractoras, el órgano competente debe eximirle de la sanción que pudiera corresponderle siempre que aporte en primer lugar elementos de prueba que permitan incoar el procedimiento o comprobar la infracción, "siempre y cuando en el momento de aportarse aquellos no se disponga de elementos suficientes para ordenar la misma y se repare el perjuicio causado". Serán requisitos para ello el cese en la participación de la infracción y que no se hayan destruido elementos de prueba relacionados con el objeto de la denuncia.

(76) Este precepto en su apartado segundo recoge el contenido mínimo de dicha orden en el caso de procedimientos de naturaleza sancionadora "en la medida de lo posible»: persona/s presuntamente responsable/s, conductas o hechos que pudieran constituir infracción administrativa y su tipificación, lugar y fecha/s o período de tiempo continuado en que los hechos se produjeron. Este mismo contenido será, en su caso también, recogido en la petición de otro órgano administrativo (art. 61.3 LPACAP). 
Estos dos últimos constituyen también presupuestos en casos de reducción de la sanción, pecuniaria o no, que pudiera imponérsele a la persona co-infractora arrepentida. El órgano administrativo resolverá reduciéndola, en lugar de eximiendo, cuando se aporten elementos de prueba que aporten un valor añadido significativo respecto a los que se disponga. La diferencia la encontramos en dicho adjetivo "significativo", en lugar del calificativo de "suficientes" utilizado para la exención según hemos descrito en el párrafo anterior (en el sentido de "elementos de prueba esenciales»). Atendiendo a dicha exención, cierto sector doctrinal los ha denominado "programas de clemencia", para criticarlos seguidamente en este ámbito administrativo por posibles usos torticeros (77).

Otra de las cuestiones a plantearnos es referida a si existe obligación de incoar expediente sancionador ante la presentación de una denuncia. Atendiendo a sentencias como la del Tribunal Supremo de 2 de noviembre de 2015 (78), la cual cita otras sentencias de 4 de diciembre de 2013 y de 12 de octubre de 2012, debemos continuar manteniendo que no existe tal derecho, sino sólo a que se investigue por la Administración el contenido de la denuncia. Cuestión distinta es que dicha persona denunciante puede recurrir en vía judicial contra la conducta omisiva administrativa con base en el artículo 25.2 de la Ley 29/1998 de la Jurisdicción Contencioso-Administrativa pues sentencias como las del Tribunal Supremo de 25 de mayo de 1987 (79) y de 4 de mayo de $1999(80)$ han considerado la obligación de incoar un procedimiento sancionador por parte de la Administración cuando ésta observa una situación indiciaria suficiente, todo ello en relación con el principio de legalidad y la interdicción de la arbitrariedad (art. 9.3 CE). Por todo ello, no puede negarse que no existe un consenso doctrinal, ni jurisprudencial respecto a esta importante cuestión, habiéndose desaprovechado en la nueva normativa procedimental la oportunidad de zanjarla una regulación clara(81). En cualquier caso, se requiere la tramitación de la denuncia $y$, en su caso, se emitirá resolución de inadmisión de la pre-

(77) En este punto, PENSADO SEIJAS, Alberto, "Estudio sobre las novedades de las Leyes 39/2015 y 40/2015...", op. cit., pág. 8. Dicho autor, siguiendo a RIVERO ORTEGA, propone que se justifique suficientemente que «no se disponía de elementos para abrir el procedimiento sancionador sin mediar una denuncia de estas características».

(78) Recurso núm. 908/2014.

(79) STS, Sala $3 .^{a}$ de lo Contencioso Administrativo, de 25 de mayo de 1987, Fundamento Jurídico $2 .^{\circ}$.

(80) Recurso núm. 646/1994.

(81) REBOLLO PUIG, Manuel, "Control judicial del no ejercicio de la potestad sancionadora", en GUILLÉN CARAMES, Javier, y CUERDO MIR, Miguel, Estudios sobre la potestad sancionadora en Derecho de la competencia. Thomson Reuters Civitas. Cizur Menor, 2015, págs. 407 y ss. 
tensión de la persona que la presentó, la cual deberá basarse en razones de legalidad y de orden público (82).

En este punto debemos mencionar la nueva regla reconocida en el artículo 63.3 de la LPACAP, de acuerdo con la cual, no es posible iniciar nuevos procedimientos de la naturaleza de los aquí tratados por infracciones administrativas en cuya comisión persista quien sea responsable de forma continuada, mientras no sea dictada una primera resolución sancionadora y ésta no sea ejecutiva. En otras palabras, en infracciones continuadas (83) (tales como las relacionadas con apertura de actividades, a modo de ejemplo) no puede iniciarse un segundo procedimiento sancionador por continuar ejerciéndose esa actividad sin la debida tramitación mientras no sea firme en vía administrativa la resolución sancionadora dictada en el primero de ellos (84). Esta prohibición es relevante en la tipificación de infracciones que incrementan su gravedad basándose en la reiteración de la conducta en los últimos años (85).

Una vez se dicte el acuerdo de incoación del procedimiento sancionador, el órgano competente debe asegurarse de que el mismo recoja el contenido mínimo requerido en el artículo 64.2 de la LPACAP: identificación de la/s persona/s presuntamente responsable/s, posibilidad de que ésta/s reconozca/n su responsabilidad con los efectos previstos en el artículo 85 de la LPACAP (añadiendo, para ello, importe aproximado de la posible sanción(86)), hechos que motivan dicho inicio los cuales tendrán el valor de presunciones (incluida su posible calificación y sanciones (87)),

(82) Nos apoyamos para esta conclusión en el artículo 34 de la LPS (que reconoce el derecho de quien denuncia «a recibir comunicación del órgano competente sobre la apertura o no de aquél y, en su caso, de la resolución que le ponga fin») en relación con el derecho a recibir respuesta expresa de toda solicitud de acuerdo con el artículo 21 de la LPACAP.

(83) A este respecto, el art. 29.6 LRJSP recoge la definición que facilitaba hasta entonces la jurisprudencia, estableciendo que son infracciones continuadas aquellas que violen el mismo o semejantes preceptos administrativos en ejecución de un plan preconcebido o aprovechando idéntica ocasión.

(84) De hecho, el artículo 98.1.b) de la LPACAP establece que las resoluciones dictadas en procedimientos sancionadores no serán ejecutivas hasta que no quepa contra ellas ningún recurso en vía administrativa, incluido el potestativo de reposición.

(85) Éste es el caso del artículo 51.13 de la Ley 10/2015, de 23 de diciembre, de Espectáculos Públicos y Actividades Recreativas, el cual tipifica como infracción muy grave el hecho de cometer una grave, «cuando hubiere sido sancionado por resolución firme en vía administrativa, en el plazo de un año, por dos o más infracciones graves".

(86) Es decir, se deberá advertir de la posibilidad de autoinculpación/allanamiento. Además, si se incorpora el importe aproximado de la posible sanción a imponer, como proponemos aquí, entendemos que se respeta la presunción de inocencia de la persona inculpada y no se prejuzga cuestión alguna del procedimiento sancionador; además de que, al mismo tiempo, se posibilita a ésta utilizar la opción del "pago voluntario" prevista en el artículo 85 de la LPACAP.

(87) Tal y como recuerda el propio artículo 64.2.b) de la LPACAP, esta identificación de hechos, junto con su calificación y las sanciones posibles, se realizará sin predeterminar nada, "sin perjuicio de lo que resulte de la instrucción"; lo contrario supondría quebrantar el principio de presunción de inocencia prevista en el artículo 53.2.b) LPACAP. De hecho, la STS de 16 de enero de 2001 ya se refirió 
identificación de las personas que realizarán las labores de instrucción y de secretaría durante la tramitación del expediente debiendo indicarse expresamente el régimen de recusación frente a ellas (88), órgano competente para la resolución y norma que le atribuya dicha potestad, indicación del derecho a formular alegaciones y a la audiencia (incluyendo plazo para ello (89)), así como las posibles medidas provisionales incoadas.

\begin{abstract}
al valor de estos hechos como «apreciaciones de carácter meramente presuntivas, destinadas precisamente a dar a conocer a los interesados la materia objeto de investigación, y a fin de que puedan desarrollar sus garantías de defensa con total plenitud». Más aún, el artículo 64.3 recoge la previsión relativa a la imposibilidad de calificar la infracción en este momento inicial cuando no existan elementos suficientes para ello; en ese caso, podría realizarse en la fase posterior de la instrucción, con el Pliego de Cargos.

Atendiendo a todas estas cuestiones, así como a las posibles reducciones previstas en los artículos 62 y 85 de la LPACAP, se recomienda que en el acuerdo de incoación se recoja una provisional calificación con sus posibles sanciones en el siguiente sentido: "dichos hechos, en principio, podrían constituir una infracción calificada como..., con motivo de la cual se podrían imponer sanciones consistentes en..." De esta manera, se respetaría la presunción de inocencia y se dejaría libertad para la instrucción del procedimiento y sus averiguaciones; pero, al mismo tiempo, la persona inculpada podría abonar la posible sanción pecuniaria reducida en el caso de que reconozca la infracción... puesto que el art. 85.3 de la LPACAP exige determinar esas reducciones "en la notificación de iniciación del procedimiento".
\end{abstract}

(88) En el supuesto de que en las personas instructora o secretaria se dé alguna de las circunstancias previstas en el artículo 23.2 de la LRJSP (interés personal, ...), siempre que no se hubiera abstenido, se promoverá recusación mediante escrito en el que se expresa la/s causa/s en que se funda (art. 24.2 LRJSP). En el supuesto de que no se especifique esta última, recomendamos remitir notificación a quien promueva tal recusación solicitándole que subsane dicha carencia (art. 71 LPACAP). Al día siguiente la persona recusada manifestará a su inmediato/a superior si concurre la causa alegada, en cuyo caso se acordará su sustitución seguidamente. Por el contrario, si se niega su existencia, dicho órgano superior resolverá en el plazo de tres días hábiles, previos los informes y comprobaciones que se consideren oportunos (art. 24, apartados tercero y cuarto, de la LRJSP); el artículo 184 del Real Decreto 2586/1986 por el que se aprueba el Reglamento de Organización y Funcionamiento de las Entidades Locales (ROF) prevé un plazo de quince días para ello. Dicha resolución no es recurrible, si bien se podrá alegar la recusación al interponer el recurso que proceda contra la resolución final. En ningún caso se alegará la causa de abstención directamente en vía la contenciosa (sin solicitar la recusación en vía administrativa), atendiendo a la STS de 1 de abril de 1996, recurso núm. 6388/1991, en su fundamento jurídico $3 .^{\circ}$.

Debemos tener en cuenta que, si estamos ante una Administración Local, decidirá la Presidencia de la misma (cuando la recusación se formule contra la instrucción y/o secretaría), o bien el Pleno (en el caso de que el órgano resolutorio sea la Presidencia y la recusación se formule contra ella), en virtud de la previsión del artículo 183 del ROF. Desde la solicitud de recusación hasta su resolución se entenderá suspendido el procedimiento sancionador (artículos 22.2.c y 74 de la LPACAP).

(89) Debe llamarse la atención sobre el peligro de lo dispuesto por el artículo 64.2.f) LPACAP puesto que, según este último apartado, debe advertirse expresamente en el acuerdo de incoación del procedimiento sancionador que, en caso de que no se presenten alegaciones en el plazo previsto, ese acto administrativo podrá ser considerado propuesta de resolución cuando contenga un pronunciamiento preciso acerca de la responsabilidad imputada. El órgano competente deberá dictar el acuerdo de inicio sin obstaculizar la separación entre la instrucción y la resolución (puesto que habitualmente en Administraciones horizontales, como un Ayuntamiento, el órgano competente para incoar y resolver es el mismo), así como sin perjudicar la presunción de inocencia con la precisión del pronunciamiento respecto a la responsabilidad imputada que exige el artículo 64.2.f) LPACAP. 
Por otra parte, atendiendo al artículo 56.1 de la LPACAP, dentro del contenido del acuerdo de incoación del procedimiento sancionador deberá incluirse también la identificación y motivación (90) de la/s medida/s cautelar/es que pudiera/n adoptarse, de oficio o a instancia de parte. Los requisitos para ello son que se estimen oportunas para asegurar la eficacia de la resolución que pudiera recaer (si existiesen elementos de juicio suficientes para ello; es decir, si se justifica su necesidad o utilidad para ello), que respeten los principios de proporcionalidad, efectividad y menor onerosidad, además de que no causen perjuicios de imposible o difícil reparación a las personas interesadas, ni impliquen violación de derechos no amparados por las leyes(91). En caso de falta de valoración individual de dichos criterios, limitándose a reproducir los preceptos legales, la jurisprudencia ha anulado ese acto administrativo adoptando una medida provisional (92). Recordemos que este tipo de medidas pueden ser confirmadas, modificadas o levantadas en cualquier momento durante la tramitación del procedimiento, de oficio o a instancia de parte, atendiendo a circunstancias sobrevenidas o que no pudieron ser tenidas en cuenta en el momento de su adopción (93).

Atendiendo al artículo 64.1 de la LPACAP(94), ese acuerdo de incoación del procedimiento sancionador será notificado individualmente a las personas interesadas, dentro de las cuales, se considerará siempre a la/s inculpada/s y, respecto a quienes denuncien, sólo cuando se les considere con intereses legítimos o derechos que pudieran verse

(90) Esta motivación también es exigida por el artículo 35.1.d) de la LPACAP. En caso de adoptarse alguna medida cautelar, se motivará la existencia de elementos de juicio suficientes para ello (necesidad, utilidad, ...) y el cumplimiento de los requisitos indicados; recordemos que no vale la reproducción de estos preceptos legales, atendiendo a las sentencias de las Salas de lo Contencioso-Administrativo delTribunal Supremo de 17 de noviembre de 2014 y a la delTribunal Superior de Justicia de Madrid de 11 de julio de 2016. Por su parte, en caso de denegación, se motivará su innecesariedad o la excesiva onerosidad de adoptar la medida solicitada...

(91) Artículo 56.4 de la LPACAP.

(92) Sentencia de la Sección $1 .^{\text {a }}$ de la Sala de lo contencioso-Administrativo delTribunal Superior de Justicia de Madrid de 11 de julio de 2016, Fundamento Jurídico 2. ${ }^{\circ}$. En sentido similar, respecto a la valoración individual de cada requisito, citaremos también la STS de 28 de febrero de 2012, recurso núm. 4396/2010.

Para una mayor desarrollo en cuanto a dichos requisitos de proporcionalidad,..., se recomienda la lectura de MARINA JALVO, Belén, "Las medidas provisionales administrativas...", op. cit., págs. 176-179.

(93) En concreto, así lo establece el apartado quinto del artículo 56 de la LPACAP.

(94) Dicho precepto parece dar cumplimiento a uno de los derechos de las personas interesadas durante la tramitación de un procedimiento sancionador regulado en el artículo 53.2 de la LPACAP.

Para una mayor profundidad respecto al régimen de notificaciones, recomendamos FERNÁNDEZ RODRÍGUEZ, Tomás Ramón, "Una llamada de atención sobre la regulación de las notificaciones electrónicas en la novísima Ley de Procedimiento Administrativo Común de las Administraciones Públicas", en RAP núm. 198, 2015, págs. 361-367. 
afectados (95). Asimismo, será comunicado a quien ejerza las labores de instrucción, con traslado de cuantas actuaciones existan al respecto; $y$, si bien no se cita, debe entenderse que también a la persona secretaria del expediente, quien continuará formando el expediente concreto en los términos del artículo 70 de la LPACAP. Por su parte, el artículo 36.2 de la LPS añade que, tras dicha notificación, las personas interesadas podrán presentar durante un plazo de quince días alegaciones, documentos o informaciones, así como solicitar la apertura de período probatorio y proponer medios de prueba; como hemos defendido en anteriores ocasiones, entendemos que este plazo se refiere a días hábiles.

\section{La ordenación e instrucción: distinción de funciones, la prueba, la propuesta de resolución y posibilidad de archivo del procedimiento administrativo sancionador común}

Como cuestión previa a analizar dentro de este epígrafe, debemos destacar el tradicional mandato de separación entre instrucción y resolución, siguiendo sentencias como la del Tribunal Constitucional n. ${ }^{\circ}$ 174/2005, de 4 de junio. Quien realice las labores de instrucción del procedimiento y quien emita la resolución final deben ser distintos órganos o personas (art. 63.1 LPACAP), todo ello con la finalidad de lograr la imparcialidad necesaria en un procedimiento que puede finalizar con consecuencias desagradables como es el caso de un sancionador. Ahora bien, dicha separación es más suave en el ámbito administrativo que en el procesal penal, atendiendo a la sentencia del mismo órgano judicial de 26 de abril de 1990 (96).

La persona instructora responderá directamente de la tramitación de ese procedimiento sancionador $y$, en especial, del cumplimiento de los plazos establecidos (97). Atendiendo a la indicada exigencia de separación, consideramos que no será posible la acumulación de dos procedimientos sancionadores con identidad sustancial o íntima conexión puesto

(95) Para llegar a esta conclusión se han relacionado los artículos 4 y 62.5 de la LPACAP. El artículo 30 de la LPS califica de interesados/as a denunciantes que tengan derechos o intereses legítimos que pudieran resultar afectados. Cuando quien denuncie no sea interesado/a, no tendrá derecho a conocer en cualquier momento el estado de tramitación del procedimiento (art. 53.1.a LPACAP), disfrutando únicamente de los de cualquier persona en sus relaciones con las Administraciones previstos en el artículo 13 de la LPACAP. Así, HERNÁNDEZ JIMÉNEZ, Hilario M., "El procedimiento sancionador en la Ley 39/2015: aplicación práctica a las infracciones urbanísticas», en Actualidad Administrativa núm. 5, 2017, pág. 4.

(96) Recurso núm. 695/1985.

(97) Así lo reconoce el artículo 71.3 de la LPACAP. Para una mayor profundidad respecto a la persona instructora (funciones,...), así como a la secretaría, HERNÁNDEZ JIMÉNEZ, Hilario M., "El procedimiento sancionador en la Ley 39/2015...», op. cit., págs. 6-7. 
que el artículo 57 de la LPACAP exige que "sea el mismo órgano quien deba tramitar y resolver el procedimiento". Estos requisitos, que provienen de los de acumulación de los procesos judiciales, como recuerda el Consejo General del Poder Judicial en su informe al anteproyecto de la LPACAP, se introdujeron en la anterior LRJPAC en 2015. En todo caso, el mismo precepto citado prohíbe la interposición de recurso contra la denegación, en su caso, de la solicitud de acumulación con motivo de la discrecionalidad administrativa del órgano competente (98).

Actualmente los artículos 75 a 81 de la LPACAP se refieren a los posibles actos de instrucción durante el expediente sancionador: alegaciones, período probatorio, informes y cuantos actos se consideren necesarios para la determinación, conocimiento y comprobación de todas las cuestiones relevantes en este tipo de procedimientos (determinación de responsable/s, hechos,...). Durante la realización de éstos se seguirán los principios y reglas tradicionales de ordenación: celeridad, uso de medios electrónicos, transparencia y publicidad (art. 71.1 LPACAP), orden riguroso cronológico salvo orden motivada (art. 71.2 LPACAP), principio de simplificación administrativa (art. 72 LPACAP), además de otras normas sobre trámites (art. 73 LPACAP). Por supuesto, en caso de que se susciten cuestiones incidentales durante el mismo procedimiento, no se suspenderá la tramitación de éste; la única excepción al respecto es la recusación de la instrucción y/o secretaría, tal y como continúa exigiendo hoy el artículo 74 de la LPACAP. Observamos, en definitiva, pocas novedades en relación con estos preceptos respecto a la anterior LRJPAC, salvo la referencia a los principios de transparencia y publicidad en el artículo 71.1 de la LPACAP entendidos como conocimiento de la tramitación en sus diferentes pasos (derecho a obtener copia de los documentos obrantes en el expediente,...).

Entre los posibles actos de instrucción, en este trabajo daremos especial relevancia al período probatorio, no sólo por ser los artículos 77 y 78 de la LPACAP los que han sufrido una mayor modificación dentro de esta fase, sino también por la importancia habitual del mismo dentro del período probatorio(99). En concreto, quien realice la funciones de instrucción comunicará, con antelación suficiente, a las personas interesadas el inicio de las actuaciones probatorias admitidas, incluyendo lugar, fecha y hora, advirtiéndoles de la posibilidad de nombrar personal técnico para que les asistan (100).

(98) Podemos citar, a modo de ejemplo, la STS de 18 de diciembre de 1998, Recurso 4795/1991, Fundamento Jurídico $22^{\circ}$.

(99) Atendiendo a la STS de 3 de febrero de 1999, Recurso núm. 2803/1993, que cita otra del mismo órgano judicial de 27 de abril de 1998, "la Administración ha de desplegar una actividad que contradiga la presunción de inocencia, cuando se trate de un proceso de tipo sancionador».

(100) Artículo 78, apartados 1 y 2, de la LPACAP. 
A este respecto, podrá admitirse cualquier medio de prueba admisible en Derecho que sirva para acreditar los hechos relevantes y que se considere pertinente, por ello; de manera que sólo podrán rechazarse las propuestas de pruebas que se consideren improcedentes o innecesarias, requiriéndose resolución motivada(101). Ahora bien, como defiende la jurisprudencia, éste no supone un derecho absoluto e incondicionado, pues se refiere sólo a las pruebas que la instrucción considere pertinentes (102) y en la forma en que se considere que deben ser practicadas (103), todo ello atendiendo a los supuestos ya conocidos del artículo 37, apartados 1 y 2, de la LPS. En este caso, atendiendo a las sentencias del Tribunal Supremo de 31 de marzo de 1998(104) o de 26 de octubre de 2000, se permitirían, incluso, hasta las denominadas pruebas indirectas o indiciarias; es decir, aquéllas que muestran "la certeza de unos hechos que no son en sí mismos los integrantes de la infracción o los determinantes de la culpabilidad, pero de los que cabe inferir lógicamente una u otra"; para ello deben probarse esos hechos indiciarios y hacerse explícito el razonamiento por el cual se obtiene la conclusión de culpabilidad, "con un enlace preciso y directo según las reglas del criterio humano" puesto que no hay duda de que a la Administración le corresponde la carga de la prueba(105).

(101) Artículo 77, apartados 1 a 3, de la LPACAP. La no admisión de alguna prueba en estos casos no impedirá continuar el procedimiento, si bien podrá alegarse en el recurso contra la resolución final del procedimiento, de conformidad con la STS de 18 de julio de 2003, Recurso núm. 11701/1998. Por su parte, el artículo 41 de la LPS permite la posibilidad de recurrir dicha denegación. El Tribunal Constitucional, en sentencia $n .^{\circ} 66 / 2007$, de 27 de marzo, exige que se haya solicitado en tiempo y forma la prueba y que sea decisiva en términos de defensa para que tenga éxito dicho recurso, teniendo la persona recurrente la carga de la prueba a este respecto.

En este punto, resulta relevante la sentencia de la Sala de lo Contencioso-Administrativo de la Audiencia Nacional de 12 de noviembre de 2014, recurso núm. 414/2012, de acuerdo con la cual, "los procedimientos administrativos sancionadores no están sujetos a todas las garantías, más estrictas, que se requieren en los procesos penales, de modo que, por ejemplo, no rigen para ellos las consecuencias del principio acusatorio en toda su extensión, ni por lo que respecta a la aportación de pruebas ni a la calificación de los hechos (Sentencia de 21 de febrero de 2006)».

(102) Es el caso de las SSTC n. ${ }^{\circ}$ 2/1987, de 21 de enero, 190/1987, de 1 de diciembre, o 192/1987, de 2 de diciembre.

(103) STC n. ${ }^{\circ} 22 / 1990$, de 15 de febrero.

(104) Recurso núm. 197/1995.

(105) STS de 17 de enero de 2011, recurso núm. 553/2009, Fundamento Jurídico $3 .^{\circ}$. Asimismo, en el mismo sentido, la STC $n .{ }^{\circ} 244 / 1994$ de 15 de septiembre; así como las del Tribunal Supremo de 31 de octubre de 2000, recurso núm. 1245/2000, y de 14 de noviembre de 2014, recurso núm. 5244/2011. Esta última concluye que, para que una prueba indiciaria pueda desvirtuar dicha presunción de inocencia "debe satisfacer las siguientes exigencias constitucionales: los indicios han de estar plenamente probados - no puede tratarse de meras sospechas - y se debe explicitar el razonamiento en virtud del cual, partiendo de los indicios probados, se ha llegado a la conclusión de que el imputado realizó la conducta infractora; pues, de otro modo, ni la subsunción estaría fundada en Derecho ni habría manera de determinar si el producto deductivo es arbitrario, irracional o absurdo". 
El artículo 299 de la Ley 1/2000, de 7 de enero, de Enjuiciamiento Civil enumera algunos de los medios probatorios posibles (interrogatorio, dictamen $(106), \ldots)$, incluyendo cualquier otro que permitiera obtener certeza sobre hechos relevantes. Destacamos la preocupación por los recursos económicos de la Administración recogida en el artículo 78.3 de la LPACAP puesto que, en caso de que las pruebas a celebrar a propuesta de parte impliquen gastos que dicha Administración no deba soportar, ésta podrá exigirle el anticipo de los mismos, a reserva de la liquidación definitiva que tendrá lugar una vez practicada la prueba; a estos últimos efectos, se añadirán los comprobantes que acrediten la realidad y cuantía de esos gastos.

En cuanto a la valoración de las pruebas, el artículo 77.1 de la LPACAP incorpora un criterio jurisprudencial al prever que ésta se realizará según las reglas de la sana crítica (107), con carácter general; es decir, de acuerdo con los criterios de la LEC. Sin embargo, deben tenerse en cuenta ciertas especificidades como sucede en cuanto a la consideración como ciertos de hechos en los que una parte ha intervenido personalmente si le perjudican a quien así lo ha declarado (art. 316 LEC), en relación con la fuerza probatoria de los documentos públicos reconocida en los artículos 319 a 323 de la LEC o la relativa a los documentos privados (art. 326 LEC), incluyendo los presentados mediante copias reprográficas (art. 334 LEC). Además de que no podemos olvidar ciertas especificidades añadidas ahora por la LPACAP: respecto a hechos declarados probados por resoluciones judiciales penales firmes (art. 77.4) o a documentos formalizados por funcionariado con condición de autoridad que cuentan con presunción de certeza iuris tantum (art. 77.5). Incluso, atendiendo a ciertas normas sectoriales, como la Ley Orgánica 3/2013, de 20 de junio, de protección de la salud del deportista y lucha contra el dopaje, sería posible solicitar las pruebas que existen en un procedimiento penal en curso. En cualquier caso, resulta imprescindible incorporar a la propuesta de resolución formulada por la instrucción la valoración de las pruebas practicadas que pudieran constituir el fundamento básico de la decisión que se

(106) Si este informe debe provenir de un órgano administrativo, el artículo 22.1.d) de la LPACAP prevé la suspensión del plazo de resolución cuando dicho informe no haya llegado. En el mismo sentido lo han defendido las SSTS de 18 de marzo de 2008, recurso 3219/2005, o de 4 de marzo de 2009, recurso 3943/2006, "cuando su contenido responsa a necesidades objetivas de la instrucción».

(107) Así se reconoce en distintos preceptos de la Ley de Enjuiciamiento Civil: en el artículo 316 en cuanto al interrogatorio de partes, en el 348 respecto al dictamen pericial, en el art. 376 sobre interrogatorio de testigos o en el 382.3 en cuanto a las pruebas obtenidas mediante instrumentos de filmación, grabación o semejantes. Para una mayor profundidad sobre el tema, GARCÍA URETA, Agustín, "Consideraciones sobre la incidencia de las Leyes 39 y 40/2015 en la Ley 2/1998...», op. cit., págs. 56-60. 
adopte en el procedimiento, por ser pieza imprescindible para la correcta evaluación de los hechos (108).

Como sabemos, una de las tareas finales de la instrucción es redactar la propuesta de resolución(109) dentro de ese procedimiento sancionador, la cual será notificada a las personas interesadas, tal y como establecen los artículos 88.7 y 89.2 ambos de la LPACAP. La omisión de este trámite que se considera esencial en el procedimiento incurre en posible nulidad, tal y como defiende la sentencia de la Sección 3. ${ }^{a}$ de la Sala de lo Contencioso-Administrativo del Tribunal Supremo de 19 de abril de 1999, recurso núm. 34/1995.

Dicha propuesta incluirá, como contenido mínimo(110), la puesta de manifiesto del procedimiento, el plazo para formular alegaciones y presentar documentos o informaciones pertinentes, fijación de los hechos probados y su exacta calificación jurídica de forma motivada, infracción que en su caso constituyan dichos hechos, persona/s responsable/s, sanción concreta propuesta, valoración de las pruebas practicadas siguiendo lo indicado anteriormente y pronunciamiento relativo a las medidas provisionales que se hubieran adoptado en su caso, siempre motivándolo e incluyendo una sucinta referencia de hechos y de fundamentos de Derecho. En estos casos, de considerarse la existencia de infracción y responsabilidad, el artículo 38.a) de la LPS añade contenido consistente en daños y perjuicios que se consideren acreditados o las actividades de reparación o indemnizaciones que se propongan. En caso contrario, en el supuesto de que se concluya la inexistencia de responsabilidad, se declarará esa circunstancia, de acuerdo con el artículo 89.3 de la LPACAP; el artículo 38.b) de la LPS antes citada añade la propuesta de absolución y la «determinación de si tal estimación se debe a una valoración probatoria o a una apreciación jurídica y el razonamiento que funda una u otra».

A pesar de ello, el artículo 89.1 de la LPACAP ha introducido una novedad al permitir a la persona instructora la adopción de acuerdo de finali-

(108) Nos referimos aquí al artículo 77.7 de la LPACAP; en el mismo sentido, STS de 18 de junio de 2012, recurso núm. 488/2011.

(109) A este momento posterior se refería el artículo 64.3 de la LPACAP.

(110) Hemos relacionado en este punto los apartados dos in fine y tres del artículo 89, así como el artículo 35.1.h), todos ellos de la LPACAP. Atendiendo a la STS de 21 de octubre de 2005, recurso núm. 5876/2002, deberán motivarse suficientemente el acuerdo de imposición de sanción en el grado que se considere, además de la existencia o no de circunstancias de graduación. Este contenido mínimo de la propuesta de resolución supone una pequeña variación respecto al anteriormente exigido, añadiéndose hoy la valoración de las pruebas practicadas en aras al derecho de defensa de la persona inculpada.

Respecto a la forma de la propuesta de resolución, no podemos olvidar los requisitos formales previstos en los artículos 34 a 36 de la LPACAP: siguiendo la normativa concreta de ese procedimiento, uso de medios electrónicos,... 
zación del procedimiento sancionador, ordenándose el archivo de las actuaciones y sin necesidad de dictar la propuesta de resolución antes citada. Esta posibilidad se reduce a los siguientes supuestos: cuando no existan los hechos que constituyeran la infracción, cuando los mismos no resulten acreditados, cuando los hechos no constituyan una infracción administrativa, cuando no exista o no se haya podido identificar a quien resulte responsable o si aparece exento/a de responsabilidad, o bien cuando se concluya que la infracción ha prescrito. Hablamos de posibilidad y no de obligación de quien instruya; es decir, el órgano instructor tendría la opción de finalizar el procedimiento según el apartado primero del artículo 89 citado(111).

Siguiendo la doctrina(112), nos planteamos tres cuestiones ante este aspecto novedoso. Por un lado, consideramos que no se infringe la regla de separación entre instrucción y resolución en el caso de que la persona instructora ordene el archivo siguiendo este artículo 89.1 de la LPACAP puesto que realmente no impone ninguna sanción. Por otro lado, entendemos que nada obsta a volver a incoar procedimiento sancionador por los mismos motivos si, dentro del plazo de prescripción de las infracciones, encontramos nuevas pruebas...que nos lleven a identificar a la persona responsable (identificación que, por ejemplo, nos faltaba cuando la instrucción ordenó ese archivo del procedimiento) o, en definitiva, a una conclusión distinta del archivo previsto en el artículo 89.1 aquí citado.Y, finalmente, consideramos que la decisión de la instrucción ordenando el archivo es recurrible en los casos en que exista denunciante que sea persona interesada (según lo argumentado al tratar la incoación de estos procedimientos sancionadores), además de en supuestos de acción pública (así en urbanismo(113), en medio ambiente(114) o en patrimonio histórico (115), entre otros) puesto que ningún sentido tendría el recurso por la persona inicialmente inculpada (116).

(111) Así se defiende también en CAMPOS ACUÑA, Concepción, Comentarios a la Ley 39/2015..., op. cit., págs. 587-588.

(112) A modo de ejemplo, citaremos a CANO CAMPOS, Tomás, «El autismo del legislador. La «nueva» regulación de la potestad sancionadora», en RAP núm. 201, 2016, págs. 47-48.

(113) Arts. 5.1.f) y 62 del Real Decreto Legislativo 7/2015, de 30 de octubre, por el que se aprueba el texto refundido de la Ley de Suelo y Rehabilitación Urbana, y art. 8.2.c de la Ley 2/2006, de 30 de junio, de Suelo y Urbanismo de la Comunidad Autónoma Vasca.

(114) Art. 22 de la Ley 27/2006, de 18 de julio, por la que se regulan los derechos de acceso a la información, de participación y de acceso a la justicia en materia de medio ambiente, así como art. 3.4 de la Ley autonómica 3/1998, de 27 de febrero, General de Protección del Medio Ambiente.

(115) Art. 8.2 de la Ley 16/1985, de 25 de junio, del Patrimonio Histórico, o el art. 3, párrafo segundo, de la Ley 7/1990, de 3 de julio, de Patrimonio Cultural de la Comunidad Autónoma Vasca.

(116) PLEITE GUADAMILLAS, Francisco, "Las nuevas facultades del instructor en el procedimiento sancionador de la Ley 39/2015, de 1 de octubre", en Actualidad Administrativa núm. 5, 2017, pág. 2. 
Sin embargo, con carácter general, la propuesta de resolución de la instrucción será notificada a las personas interesadas, quienes podrán presentar alegaciones... durante el plazo previsto en la normativa aplicable. A este respecto, el artículo 39 de la LPS establece un plazo de alegaciones de quince días hábiles (117), así como la garantía de que durante el mismo se podrá consultar el expediente y obtener copias del mismo. Atendiendo a la sentencia n. ${ }^{\circ}$ 29/1989 del Tribunal Constitucional, de 6 de febrero, esta notificación es una manifestación del derecho de toda persona a ser informada de la acusación contra ella.

Tras la finalización de dicho período quien instruya el procedimiento dará traslado del expediente y de todas las actuaciones al órgano competente para resolver(118), dentro de las cuales entendemos que debe incluirse el informe de la instrucción en el supuesto de que se hayan presentado alegaciones durante ese trámite de audiencia citado (119). Ahora bien, antes de emitir dicha resolución administrativa, el artículo 87 de la LPACAP continúa la regulación del artículo 20.2 del REPEPOS al prever la posibilidad de que este último órgano emita un acuerdo motivado(120) para realizar las actuaciones complementarias que se consideren indispensables para resolver el procedimiento; no se considerarán como tal los informes que precedan a la resolución final. Estas actuaciones deberán practicarse en un plazo no superior a quince días hábiles.

\section{Principales aspectos durante la fase de finalización del procedimiento sancionador}

Existen diversas modalidades de terminación de un procedimiento sancionador, atendiendo a las posibilidades reconocidas por el artículo

(117) El artículo 40 de la LPS permite la posibilidad de reducir (40.1) o de ampliar (40.2) tanto dicho plazo de alegaciones, como el de duración del período probatorio.

(118) En el mismo sentido se refiere el art. 39.2 LPS. Por lo demás, nada se suele decir en la normativa al respecto, si bien consideramos recomendable que la instrucción emita un informe final analizando las alegaciones que pudieran presentarse durante este segundo plazo tras la notificación de la propuesta de resolución, con el fin de trasladar todo el expediente al órgano competente para emitir resolución final.

(119) En este sentido, siguiendo la posibilidad del artículo 23.5 del Real Decreto 2063/2004 por el que se aprueba el Reglamento General del régimen sancionador tributario, se pronuncia HERNÁNDEZ JIMÉNEZ, Hilario M., «El procedimiento sancionador en la Ley 39/2015: ...», op. cit., págs. 11-12.

(120) Atendiendo al segundo párrafo del artículo 87 de la LPACAP, este acuerdo se notificará a todas las personas interesadas, concediéndoles un nuevo plazo de siete días hábiles para realizar alegaciones (quienes podrán oponerse por su oportunidad, ..., en cualquier momento anterior a la práctica de dichas actuaciones; recomendamos en este punto acudir a la STS de 21 de febrero de 2006, recurso núm. 1451/2002). El plazo de resolución del procedimiento sancionador quedará suspendido desde la adopción de dicho acuerdo y hasta la terminación de estas actuaciones complementarias (art. 22.2.b LPACAP, en relación con el 43.2 de la LPS). 
84 de la LPACAP: resolución administrativa, declaración de caducidad del citado procedimiento en el caso de haberse superado el plazo máximo para emitir y notificar la resolución final (121), o imposibilidad material de continuar el procedimiento por causas sobrevenidas (122) (por ejemplo, en caso de fallecimiento de la persona responsable durante la tramitación,...). Entendemos que no cabe el desistimiento, ni la renuncia al derecho en que se funda la solicitud, previstas en el artículo 84.1 de la LPACAP, puesto que un procedimiento sancionador se incoa siempre de oficio, a pesar de la posible existencia de una denuncia. Tampoco parece posible una terminación convencional pues la materia sancionadora se ha considerado tradicionalmente como no susceptible de transacción, relacionando el artículo 86.1 con el 90.4(123), ambos de la LPACAP; ahora bien, no puede negarse que esta posibilidad está prevista expresamente en materias como la de defensa de la competencia (124). Finalmente, respecto a los procedimientos sancionadores se añade otra posibilidad de finalización: el pago voluntario

(121) El artículo 25.1.b) de la LPACAP prescribe que en estos supuestos el órgano competente para resolver emita resolución indicando este hecho de la caducidad y ordenando el archivo de las actuaciones, con los efectos previstos en el artículo 95 de la misma norma legal; asimismo, el artículo 21.1 de la LPACAP requiere que se incorporen a la resolución la indicación de los hechos producidos y de las normas aplicables. Emitir una resolución es obligatorio en todo caso (art. 21.1 LPACAP). Como ya sabemos, la caducidad por sí sola no produce la prescripción de las acciones de la Administración, si bien no se interrumpirá el plazo de prescripción; por lo tanto, en caso de que no haya prescrito la infracción administrativa, podrá incoarse un nuevo procedimiento sancionador (art. 95.3 LPACAP). Para una mayor profundidad respecto a esta última idea, LÓPEZ RAMÓN, Fernando, "La caducidad del procedimiento de oficio» en RAP núm. 194, 2014, págs. 11-47.

(122) En estos casos el artículo 84.2 de la LPACAP exige que se dicte una resolución motivada por parte del órgano competente para resolver, la cual entendemos que deberá especificar la circunstancia sobrevenida que se ha producido, además de los hechos producidos y las normas aplicables, tal y como exige el artículo 21.1 de la LPACAP. A este respecto, la sentencia de la Sección 2. ${ }^{a}$ de la Sala de lo Contencioso-Administrativo del Tribunal Superior de Justicia de las Canarias, las Palmas, de 23 de abril de 2010, recurso núm. 217/2009, exige que estemos ante obstáculos físicos, tangibles o corpóreos que impiden la continuación del correspondiente procedimiento.

(123) El artículo 90.4 de la LPACAP prevé que el procedimiento complementario para fijar la indemnización por daños y perjuicios causados a la Administración Pública «será susceptible de terminación convencional» al recoger diversas especialidades de la resolución en los procedimientos sancionadores. Por lo tanto, a sensu contrario, entendemos que el procedimiento principal, el sancionador, no lo sería.

(124) En concreto, el artículo 52 de la Ley 15/2007, de 3 de julio, de Defensa de la Competencia prevé la posibilidad de terminación convencional del procedimiento sancionador, siempre las personas inculpadas "propongan compromisos que resuelvan los efectos sobre la competencia derivados de las conductas objeto del expediente", siempre que quede garantizado el interés público y siempre que la Dirección de Investigación no haya elevado la propuesta de resolución. Dicha opción es reconocida en la STS de 24 de septiembre de 2015, recurso núm. 725/2013, la cual concluye que no se está ante un derecho de dichas personas inculpadas, sino ante una posibilidad de finalización cuya denegación debe ser motivada. Para un mayor detalle, FONT I LLOVET, Tomás et. al., "Notas de jurisprudencia contencioso-administrativa» en RAP núm. 198, 2015, págs. 257 a 263 . 
(art. 85 LPACAP), también denominado allanamiento por cierto sector doctrinal (125), de lo cual trataremos seguidamente.

En concreto, en el supuesto de finalización mediante resolución expresa, ésta decidirá todas las cuestiones planteadas por las personas interesadas y aquellas otras derivadas del mismo, incluyendo motivación de sus decisiones con sucinta referencia de fundamentos de Derecho; así como indicación de los recursos que procedan, órgano administración o judicial ante el que presentarlos y plazo para hacerlo, sin perjuicio de que las personas interesadas pudieran presentar cualquier otro que estimen oportuno (126). Asimismo, se recogerá la valoración de las pruebas practicadas, especialmente de aquéllas que constituyan el fundamento básico de la decisión; además de fijar los hechos (127) y, en su caso, la responsabilidad, la/s infracción/es cometida/s con la/s sanción/es impuestas o bien la declaración de no existencia de infracción o responsabilidad (art. 90.1 de la LPACAP). A su vez, relacionando los artículos 43.1 y 38 de la LPS, podemos añadir a dicho contenido, en su caso, la «suspensión de la ejecución de la sanción de ejecución fraccionada o de su modificación y las razones de tal proposición", además de "La alteración de la situación precedente que considere ocasionada por la infracción y los daños y perjuicios derivados de la misma que considere acreditados, las razones de tales consideraciones, las actividades de reparación o indemnizaciones que se propongan y las razones de esta proposición".

Por lo demás, tenemos en el artículo 88.4 de la LPACAP otra referencia a la e-Administración al establecer que dicha resolución será emitida electrónicamente (128), garantizando la identidad del órgano competente, además de la autenticidad e integridad del documento que se formalice. Esta forma de la resolución y la garantía de la identidad del órgano competente ya venían adelantadas en el artículo 38.1 de la Ley 11/2007, de 22 de junio, de Acceso Electrónico de los Ciudadanos a los Servicios Públicos. Conviene advertir que, en el supuesto de que el órgano competente para resolver considere una mayor gravedad de la infracción o sanción respecto a la considerada por la instrucción en la propuesta de resolu-

(125) En este punto, recomendamos la reflexión realizada por DíEZ SASTRE, Silvia, «Potestad y procedimientos sancionadores" en VELASCO CABALLERO, Francisco, Régimen jurídico y procedimiento administrativo de los gobiernos locales. La aplicación a las entidades locales de las Leyes 39/2015 y 40/2015, de 1 de octubre. Instituto de Derecho Local. Madrid, 2016, págs. 173-209.

(126) Hemos relacionado para ello los apartados primero y tercero del artículo 88 con el 35.1.h, ambos de la LPACAP.

(127) Atendiendo al artículo 90.2 de la LPACAP, estos hechos aceptados no podrán ser distintos de los determinados en el curso del procedimiento sancionador, si bien sí es posible calificar jurídicamente de forma distinta esos mismos hechos declarados probados durante el indicado procedimiento.

(128) En el mismo sentido, artículo 36.1 de la LPACAP. 
ción, se notificará previamente a la persona inculpada concediéndole un plazo de quince días hábiles de alegaciones (129).

La resolución (130) en caso de allanamiento podrá ser emitida en cualquier momento, si atendemos a la previsión del artículo 85.1 de la LPACAP puesto que podrá resolverse el procedimiento con la imposición de la sanción que proceda si la persona infractora reconoce su responsabilidad, sin necesidad de trámite adicional alguno; en otras palabras, se trata de una potestad discrecional de la Administración que requiere el reconocimiento expreso y claro de su responsabilidad por parte de la persona inculpada. Si la Administración tuviera dudas sobre algún extremo (por si hubieran participado más personas,...) o si así lo considerase por interés general, la Administración podría continuar con el procedimiento sancionador. No se concreta en el precepto regulador el límite temporal para presentar esta autoinculpación, si bien por ese mismo motivo podría entenderse que en cualquier momento entre la iniciación y la resolución del procedimiento(131). A este allanamiento cierto sector doctrinal(132) lo considera general.

En este caso, cuando, además, se desista o renuncie a cualquier acción o recurso en vía administrativa, el órgano competente para resolver aplicará una reducción de al menos el $20 \%$ sobre el importe de la sanción propuesta; por lo tanto, se podría interponer recurso contencioso-administrativo, además de resultar lógico permitir también el recurso extraordinario de revisión por los plazos y naturaleza del mismo (133). $\mathrm{Si}$, asimismo, se abona voluntariamente la cuantía de la sanción pecuniaria, aplicará otra reducción de, al menos, el 20\% también(134). Por

(129) Artículo 90.2 de la LPACAP, el cual incluye como novedad la posibilidad de mayor gravedad de la sanción (respecto al tenor literal del art. 20.3 del REPEPOS antes vigente).

(130) Defendemos dictar una resolución por el órgano competente en esos casos, aplicando directamente la sanción, sin trámite adicional alguno. En concreto, proponemos resolución, de acuerdo con la cual, se acuerde "dar por terminado el expediente sancionador incoado a..., con motivo de..., al haberse abonado sanción económica por importe de... euros (cantidad resultante tras la aplicación de reducción de... \%)».

(131) Recomendamos a este respecto la reflexión que realiza GRIJALBA LÓPEZ, Juan Carlos, "Sobre el art. 85 de la Ley 39/2015, de 1 de octubre, del Procedimiento Administrativo Común de las Administraciones Públicas", en Actualidad Administrativa núm. 7-8, págs. 2-3. En cualquier caso, se precisará resolución que reconozca dicha reducción, no pudiendo prescindirse de propuesta de resolución.

(132) DÍEZ SASTRE, Silvia, "Potestad y procedimientos sancionadores» en VELASCO CABALLERO, Francisco, Régimen jurídico y procedimiento administrativo..., op. cit., págs 173-209.

(133) En este sentido, CAMPOS ACUÑA, Concepción, Comentarios a la Ley 39/2015..., op. cit., pág. 572. El motivo hemos dicho que lo encontramos atendiendo a su naturaleza de extraordinario contra actos firmes (art. 113 de la LPACAP), además de a los plazos del mismo (tres meses en la más rápida de las opciones: art. 125.2 de la LPACAP).

(134) Siguiendo el artículo 188.3 de la Ley 58/2003, de 17 de diciembre, General Tributaria (LGT), que prevé una posible reducción del $25 \%$, en relación con la resolución del Tribunal Ecónomico-Ad- 
supuesto, el artículo 85 prevé la posibilidad de incremento de estos porcentajes reglamentariamente, de manera que ambas reducciones son autónomas; incluso, vemos posible dicho aumento vía norma legal, como sucede con el artículo 232.2 de la Ley 2/2006 de Suelo y Urbanismo de la Comunidad Autónoma Vasca o con el 161.4 de la Ley 2/2016 de Suelo de Galicia(135). Todas estas opciones de "pago voluntario", que podrá efectuarse mediante cualquiera de los medios descritos en el artículo 98.2 de la LPACAP (tarjeta de crédito,...), son consideradas especiales por el mismo sector doctrinal antes citado, válidas sólo para sanciones pecuniarias. Si bien este artículo 85 es una novedad en una norma de procedimiento administrativo común, las reducciones ya eran reconocidas por diversas normas sectoriales; es el caso del Real Decreto Legislativo 6/2015, de 30 de octubre, por el que se aprueba el texto refundido de la Ley sobre Tráfico, Circulación de Vehículos a Motor y Seguridad Vial (art. 94), o de la Ley 2/2006, de 30 de junio, de Suelo y Urbanismo de la Comunidad Autónoma Vasca (art. 232.2). El objetivo es simplificar los procedimientos administrativos.

Recordemos en este punto también la reducción a imponer cuando quien denuncie haya co-participado en la comisión de la infracción pero facilite elementos de prueba que aporten un valor añadido significativo respecto de los que se disponga; además de la obligación de exención a dicha persona denunciante cuando aporte en primer lugar elementos de prueba que permitieron incoar el procedimiento o comprobar la infracción(136). Siguiendo la doctrina(137), parece que la clemencia aquí prevista, ya reconocida en materia económica (138), se ha generalizado ahora para todos los procedimientos sancionadores, si bien de una lectura conjunta de los apartados tercero y cuarto del artículo 62 de la LPACAP de-

\footnotetext{
ministrativo Central de 29 de noviembre de 2012 interpretando dicho precepto, se puede considerar que es posible fraccionar este pago y no haberlo abonado íntegramente antes de emitirse la resolución finalizadora. Ningún riesgo observamos puesto que el artículo 65.3 de la LGT permite exigir garantizar las deudas aplazadas o fraccionadas. En el mismo sentido de reducción compatible con aplazamiento o fraccionamiento, tenemos el artículo 193 de la Norma Foral 2/2005, de 10 de marzo, GeneralTributaria de Bizkaia.
}

(135) De igual forma se pronuncia PENSADO SEIJAS, Alberto, «EI aspecto sancionador en la regulación de las actividades económicas en Galicia, tras la Ley 39/2015, de 1 de octubre, del procedimiento administrativo común y otras cuestiones prácticas", en El Consultor de los Ayuntamientos núm. 21, 2017, pág. 3. Asimismo, el mismo autor en «Estudio sobre las novedades de las Leyes 39/2015 y 40/2015...", op. cit., pág. 10.

(136) Recordemos que el artículo 62.4 de la LPACAP requería para la exención que en el momento de aportarse aquellos elementos de prueba no se dispusiera de los suficientes para ordenar la misma y que se repare el perjuicio causado a la Administración.

(137) Para una mayor profundidad respecto a dicha posibilidad de clemencia, recomendamos CANO CAMPOS, Tomás, "El autismo del legislador...», op. cit., 2016, págs. 56-59.

(138) Es el caso del artículo 65 de la Ley 15/2007, de 3 de julio, de Defensa de la Competencia. 
fendemos que nos referimos sólo a infracciones administrativas que causen un perjuicio en el patrimonio de las Administraciones Públicas. Respecto a este concepto de patrimonio, mostramos nuestra conformidad con una interpretación más amplia que la recogida en el artículo 3 de la Ley 33/2003, de 3 de noviembre, de Patrimonio de las Administraciones Públicas, tal y como defiende CANO CAMPOS.

Por último, en relación con la resolución del procedimiento sancionador, resaltaremos otra de las grandes novedades de esta LPACAP: su ejecutividad. De conformidad con los artículos 90.3 y 98.1.b) de la LPACAP, una resolución sancionadora será ejecutiva cuando no quepa contra ella ningún recurso ordinario en vía administrativa, pudiendo adoptarse en la misma las disposiciones cautelares precisas para garantizar su eficacia en tanto no sea ejecutiva y que podrán consistir en el mantenimiento de las medidas provisionales que, en su caso, se hubieran adoptado, llegando incluso a extenderse a la vía contencioso-administrativa(139). Cuando la resolución sea ejecutiva, se podrá suspender cautelarmente si la persona interesada manifiesta a la Administración su intención de interponer recurso contencioso-administrativo contra la resolución firme en vía administrativa. Ahora bien esta última suspensión cautelar finalizará en los casos previstos en el propio artículo 90.3 de la LPACAP: ante el transcurso del plazo legalmente previsto sin haberse interpuesto el recurso contencioso-administrativo o cuando, habiéndose presentado el mismo, no se hubiera solicitado la suspensión cautelar en el mismo trámite o bien el órgano judicial se pronuncie sobre dicha suspensión. Destacaremos en este punto la previsión autonómica de que la resolución sancionadora ex-

(139) Atendiendo al artículo 117.4 de la LPACAP, se permite extender los efectos de las medidas cautelares que existieran, al menos, hasta que se produzca el correspondiente pronunciamiento judicial sobre la solicitud previa de la persona interesada (en el sentido de mantener las indicadas medidas). Si bien parece una novedad, ya se pronunciaba en similar sentido la STC n. ${ }^{\circ} 78 / 1996$, de 20 de mayo, o la STS de 2 de diciembre de 2011 (recurso núm. 508/2010), además de normas sectoriales como el Real Decreto 2.063/2004, de 15 de octubre, por el que se aprueba el Reglamento general del régimen sancionador tributario (art. 29). De hecho, esta última resolución judicial citada, de 2 de diciembre de 2011, considera dicha suspensión un deber de la Administración, no una facultad (especialmente, Fundamentos Jurídicos tercero y quinto).

Ahora bien, en el caso de que se deniegue dicha suspensión en vía judicial, la STS de 10 de diciembre de 2012, recurso núm. 2381/2011, prevé que se ejecute la sanción, devolviéndose la fianza en su caso presentada con motivo de dicha suspensión, puesto que, en otro caso, podría prescribir la misma al seguir computándose dicho plazo durante la resolución del recurso judicial. Para una mayor profundidad, GARCÍA VERA, Francisco Javier, "La suspensión de las sanciones a efectos de la prescripción de la acción recaudatoria» en El Consultor de los Ayuntamientos núm. 11, 2017, pág. 1.491.

Destaquemos en este punto la STC 37/2012, de 19 de marzo, de acuerdo con cuyo fundamento jurídico $10 .^{\circ}$, si la Administración incumpliese su obligación legal de resolver el recurso administrativo ordinario interpuesto, la persona recurrente podía optar por acudir a la vía judicial contra esa desestimación presunta, o bien esperar a la resolución expresa del recurso (manteniéndose hasta tanto la inejecutividad de la sanción). Por lo demás, respecto a dicha solicitud en vía contenciosa, acudiremos al artículo 129 y siguientes de la Ley 29/1998, de 13 de julio, de la Jurisdicción ContenciosoAdministrativa. 
presa adopte "en su caso, las disposiciones cautelares precisas para garantizar su eficacia en tanto no sea ejecutiva» (140).

Recordemos, siguiendo el artículo 56.5 de la LPACAP, que cuando surta efectos la resolución administrativa sancionadora, se extinguirán las medidas provisionales que pudieran haber sido adoptadas durante dicho procedimiento. La única excepción es la posibilidad de extensión de efectos antes descrita hasta el procedimiento contencioso-administrativo. En cualquier caso, podemos ver que las medidas provisionales en esta fase continúan con las mismas notas de provisionalidad y de la finalidad cautelar de asegurar la eficacia de la resolución (141).

En el supuesto de que se imponga una sanción mediante la indicada resolución expresa y de que la misma no sea abonada o ejecutada por la persona considerada responsable, se procederá a la ejecución forzosa de conformidad con las reglas de los artículos 99 a 104 de la LPACAP. En concreto, destacaremos las siguientes opciones: apremio sobre el patrimonio (142) (sanciones pecuniarias - art. 101 LPACAP-), ejecución subsidiaria (podría tener lugar en caso de precisarse precinto de unos equipos sonoros de una actividad hostelera por ser éste un acto no personalísimo - art. 102 LPACAP_) o compulsión sobre las personas (para actos personalísimos como podría ser un desahucio en caso de imponerse como sanción una prohibición de uso, por ejemplo, - art. 104 LPACAP-).

Por otro lado, el artículo 90.4 de la LPACAP, en relación con el artículo 28.2 de la LRJSP, prevé la posibilidad de que el órgano al que corresponda el ejercicio de la potestad sancionadora incoe un procedimiento complementario en los casos de daños o perjuicios a la Administración cuando su cuantía no hubiera quedado determinada en el expediente sancionador (143). La finalidad de este último procedimiento será fijar dicha cuantía, por lo tanto; de manera que su resolución pondrá fin a la vía administrativa y será inmediatamente ejecutiva(144), al contrario de lo que hemos visto para el procedimiento principal. También se posibilita expresamente que este procedimiento finalice mediante terminación con-

(140) Artículo 43.5, segundo párrafo, de la LPS.

(141) En este sentido, MARINA JALVO, Belén, "Las medidas provisionales administrativas...", op. cit., pág. 165.

(142) Arts. 167 a 177 de la Norma Foral 6/2005, de 28 de febrero, General Tributaria de Álava; la n. ${ }^{\circ} 4 / 2005$, de 10 de marzo, del mismo nombre en el caso de Bizkaia y la Norma Foral 4/2005, de 8 de marzo, General Tributaria de Gipuzkoa, cada uno según su ámbito territorial. Por su parte, en el ámbito territorial estatal se seguirá el procedimiento de apremio descrito en los artículos 167 a 173 de la LGT y Título III del Real Decreto 939/2005, de 29 de julio, por el que se aprueba el Reglamento General de Recaudación.

(143) Dicha previsión normativa, antes recogida en el artículo 22.1 del REPEPOS, ha sido hoy elevada a rango legal con su inclusión en los artículos 90.4 LPACAP y 28.2 LRJSP.

(144) Artículo 114.1.f) de la LPACAP. 
vencional; no obstante, ni ésta, ni la aceptación por la persona infractora de la resolución que pudiera recaer implicarán el reconocimiento voluntario de su responsabilidad. Finalmente, en el supuesto de no satisfacerse dicha indemnización, se incoará procedimiento de apremio, siguiendo la previsión de los artículos 28.2 de la LRJSP y 101 de la LPACAP.

Por último, como sabemos, también convivirán estos procedimientos con otros complementarios; a modo de ejemplo, citaremos por clásico el de restauración de la legalidad urbanística. Así se ha pronunciado el Tribunal Supremo en Auto de 28 de septiembre de 2012 (145) o en sentencia de 20 de abril de 2012(146); observamos en ambos el carácter complementario de este procedimiento, cuando ambas conclusiones concluyen que la anulación de la resolución sancionadora no conlleva la de la obligación de restablecer la legalidad urbanística, ... Tanto la «reposición a su estado originario de la situación alterada por la infracción", como el procedimiento complementario de indemnización por daños y perjuicios ya venían reconocidos como compatibles con la resolución dentro del procedimiento sancionador por el artículo 12 de la LPS.

\section{La tramitación simplificada en el procedimiento administrativo sancionador común}

Durante los subapartados anteriores hemos tratado la tramitación ordinaria del procedimiento administrativo sancionador común. Sin embargo, sin duda una de las grandes novedades la encontramos en la tramitación simplificada del procedimiento sancionador, la cual asimismo es una de las cuestiones que ha recibido mayores críticas en un inicio. Ésta es quizás una de las manifestaciones más claras del principio de simplificación administrativa previsto en el artículo 72.1 de la LPACAP. Ahora bien, realmente debemos reconocer que ya contábamos con antecedentes similares; es el caso del procedimiento abreviado que se preveía para todo procedimiento sancionador cuando existieran elementos de juicio suficientes para calificar la infracción como leve tanto para todo procedimiento sancionador (arts. 23 y 24 del REPEPOS). Asimismo, hoy observamos otra manifestación similar en procedimientos disciplinarios incoados con motivo de "faltas leves", exigiéndose únicamente audiencia de la persona inculpada (art. 98.1.2. ${ }^{\circ}$ del Real Decreto Legislativo 5/2015, de 30 de octubre, por el que se aprueba el texto refundido del Estatuto Básico del Empleado Público).

(145) Recurso núm. 431/2012.

(146) Recurso núm. 503/2010. 
De conformidad con el artículo 96.5 de la LPACAP, el órgano competente para incoar dicho procedimiento podrá seguir este tipo de tramitación cuando considere, de acuerdo con su normativa reguladora, que existen elementos de juicio suficientes para calificar la infracción como leve, siempre que lo aconsejen razones de interés público o no estemos ante un procedimiento que se prevea complejo (147). Frente a dicha decisión no cabe la oposición expresa por parte de la persona interesada; por lo tanto, es de prever que la virtualidad de dicha tramitación será mayor que la criticada por el Consejo General del Poder Judicial en su dictamen al Anteproyecto de la LPACAP, de 5 de marzo de 2015(148).

El apartado sexto del artículo 96 de la LPACAP exige que el procedimiento sea resuelto en treinta días hábiles(149), a contar desde el día siguiente al de notificación del acuerdo de tramitación simplificada. Durante dicho período de tiempo se realizarán los siguientes trámites: además de la incoación, trámite de audiencia con alegaciones formuladas al inicio del procedimiento durante cinco días hábiles, informes del servicio jurídico, del Consejo General del Poder Judicial y/o del Consejo de Estado u órgano autonómico consultivo equivalente cuando sean preceptivos (lo cual no sucede en un procedimiento sancionador, donde únicamente tendremos informe jurídico, en principio), así como resolución final. No se recoge ningún periodo probatorio, con lo que parece que quedan diluidas las funciones de la instrucción en este procedimiento, siguiendo cierto sector doctrinal (150). En conclusión, atendiendo a los trámites requeridos, además de a la necesidad de separación entre órgano instructor y sancionador consideramos que debe tenerse cuidado con la utilización de este procedimiento simplificado en la materia objeto del presente artículo (151).

(147) Estas dos limitaciones relativas al interés público y a la falta de complejidad las encontramos en el apartado primero del artículo 96 de la LPACAP.

(148) En el indicado dictamen el Consejo General del Poder Judicial criticaba la previsión del artículo 96.2 de la LPACAP: «debe advertirse acerca de la escasa virtualidad que presenta el interés general como motivo justificador de la tramitación de oficio del procedimiento simplificado, cuando ésta se encuentra subordinada al consenso de los interesados".

(149) Consideramos que serán días hábiles, atendiendo a la regla general del artículo 30.1 de la LPACAP. Ahora bien, dicho precepto no establece ninguna consecuencia en el supuesto de que el procedimiento simplificado no logre tramitarse en ese plazo de treinta días hábiles; entendemos que habrá de estarse a la regla general de caducidad con archivo del expediente, por tratarse de un procedimiento incoado de oficio y con posibles efectos desfavorables (art. 25.b de la LPACAP).

(150) HERNÁNDEZ JIMÉNEZ, Hilario M., "El procedimiento sancionador en la Ley 39/2015: ...», op. cit., pág. 8.

(151) Una posibilidad en este sentido sería que la persona instructora conceda siempre un trámite de audiencia al notificar su propuesta de resolución. Atendiendo a que ese trámite de audiencia no es preceptivo, consideramos que no se estaría incumpliendo la regla del artículo 96.7 de la LPACAP. 


\section{Posibilidad de interponer recurso frente a la resolución finalizadora de un procedimiento sancionador administrativo}

Tratándose de un acto administrativo que decide directa o indirectamente el fondo del asunto y que finaliza el procedimiento, las personas interesadas podrán interponer contra la resolución final tanto de una tramitación ordinaria, como de la simplificada, recurso de alzada (cuando no pongan fin a la vía administrativa, lo que suele suceder cuando existe superior jerárquico(152)) o recurso potestativo de reposición (en el resto de supuestos (153)). En el caso del procedimiento complementario de determinación de la cuantía de los daños y perjuicios causados, previsto en el artículo 90.4 de la LPACAP, se prevé expresamente que su resolución pone fin a la vía administrativa, con lo que sólo procederá contra la misma recurso potestativo de reposición (154). Nada de lo afirmado obsta a la posibilidad de interposición de recurso extraordinario de revisión contra la resolución sancionadora que sea firme en vía administrativa cuando concurra alguna de las circunstancias previstas en el artículo 125.1 de la LPACAP(155).

Hemos tratado anteriormente la posibilidad de suspensión de la ejecución de la resolución sancionadora. Recordemos que esa resolución no era ejecutiva hasta que no se pudiera interponer ningún recurso ordinario en vía administrativa, pudiendo suspenderse cautelarmente incluso (artículo 90.3 de la LPACAP). Este último precepto debemos ponerlo en relación con el artículo 117 de la LPACAP, que también se refiere brevemente a la posibilidad de suspender la resolución cuando así se solicite junto a la interposición del recurso administrativo, previa ponderación entre el perjuicio que se causaría al interés público con dicha suspensión y el ocasionado al recurrente con la eficacia del acto recurrido, siempre que su ejecución pudiera causar perjuicios de imposible o difícil reparación y que la impugnación se base en alguna de las causas de nulidad de pleno Derecho. Como podemos comprobar, se continúa con la regulación del anterior artículo 111 de la LRJPAC. En este punto consideramos que las sanciones pecuniarias difícilmente serían suspendidas atendiendo únicamente a este precepto, salvo que la parte recurrente probase(156) su con-

(152) Artículo 121 de la LPACAP.

(153) Artículo 123 en relación con el 114, ambos de la LPACAP.

(154) Artículo 114.1.f) de la LPACAP.

(155) Respecto al recurso extraordinario de revisión, relacionemos los artículos 113,125 y 126 de la LPACAP.

(156) Atendiendo a la sentencia de la Sala de lo Contencioso-Administrativo del Tribunal Superior de Justicia de Canarias de Las Palmas de Gran Canaria de 8 de julio de 2016, fundamento jurídico primero, la persona recurrente «tiene la carga de probar adecuadamente qué daños y perjuicio de reparación imposible o difícil concurren en el caso", sin que sea suficiente una mera invocación genérica. 
creta situación económica y perjuicios de gran entidad con motivo de la cuantía de la multa, siguiendo sentencias como las del Tribunal Supremo de 10 de julio de 1991, 16 de octubre de 1992 o de 7 de octubre de 2003. Ahora bien, a pesar de que se resuelva en sentido desestimatorio el recurso administrativo interpuesto, defendemos el mantenimiento de la suspensión hasta el pronunciamiento del órgano jurisdiccional competente respecto a la medida cautelar(157), siguiendo sentencias como la delTribunal Supremo de 26 de abril de 2016(158).

\section{Conclusiones}

A lo largo de este artículo hemos podido comprobar que la entrada en vigor de la LPACAP y de la LRJSP ha modificado en algunas cuestiones bastante sustanciales la tramitación del procedimiento administrativo sancionador general, sin perjuicio de trámites adicionales que puedan ser establecidos por una ley sectorial, además de ciertas especialidades reglamentarias en cuanto a plazos u órganos competentes. En consecuencia, este procedimiento administrativo común es probable que quede bastante desdibujado con motivo de dichas posibles especialidades. La nueva normativa sectorial que se apruebe seguidamente deberá tener en cuenta las diversas novedades aquí analizadas puesto que, en caso contrario, la remisión en plano al procedimiento general con ciertas especialidades realizadas en esa norma especial puede plantear diversos problemas.

En definitiva, mostramos nuestra conformidad con cierto sector doctrinal(159) que critica la regulación de esta materia sancionadora administrativa de forma parcial y confusa a lo largo de diversos preceptos de dos leyes distintas, la LPACAP y la LRJSP; así, se ha planteado en el presente artículo cierta problemática respecto al grado de autoría de una infracción o, incluso, respecto a la consideración de la persona denunciante como interesada(160) o la falta de identificación de la causa de recusación que

(157) Debemos especificar que este órgano judicial no se ve vinculado por la suspensión producida siguiendo la normativa de procedimiento administrativo común, sino que debe emitir su decisión sobre la medida cautelar de suspensión con base «al régimen de medidas cautelares establecido en los arts. 129 a 136 de la Ley de esta Jurisdicción» (STS de 11 de marzo de 2009, recurso núm. 10455/2004).

(158) Recurso núm. 1789/2015.

(159) Entre otros, CANO CAMPOS, Tomás, "La potestad sancionadora de la Administración: una regulación fragmentaria, incompleta y perniciosa" en Documentación Administrativa núm. 5, 2015, pág. 2. Las ideas planteadas en dicho artículo son desarrolladas por el mismo autor en «El autismo del legislador...", op. cit., págs. 30-32.

(160) Así lo consideramos cuando esa persona tenga derechos o intereses legítimos que pudieran resultar afectados con el procedimiento sancionador cuyo inicio se solicita (arts. 4 y 62.5 de la LPACAP, en relación con el art. 30 LPS). 
se pudiera plantear (161). Además de echar en falta otras cuestiones como una regulación completa y clara de los concursos de infracciones y de normas, la edad mínima para sancionar, las causas de extinción de la responsabilidad o si existe obligación de incoar un procedimiento sancionador una vez se constate una infracción(162).

Todo ello nos lleva a concluir que el procedimiento sancionador aquí descrito, en su tramitación ordinaria, mantiene las principales características de la normativa anterior, si bien se han incorporado diversas cuestiones jurisprudenciales (como es el caso de la ejecutividad de las sanciones, entre otras) y se ha dado una mayor sustancialidad a la instrucción del mismo procedimiento, la cual puede incluso decidir el archivo del expediente en los supuestos concretos descritos en el artículo 89.1 de la LPACAP. Ahora bien, tampoco podemos dejar de mencionar novedades dentro del procedimiento administrativo común, tales como la ampliación de sujetos responsables(163), la definición de infracción continuada (164) o la nueva fijación de la ejecutividad cuando la resolución sea firme en vía administrativa $y$, especialmente, las exenciones o reducciones por clemencia(165) o por autoinculpación(166), además de la tramitación simplificada del procedimiento sancionador (que prevé un procedimiento diferenciado descrito en el artículo 96 de la LPACAP).

Trabajo recibido el 20 de enero de 2018

Aceptado por el Consejo de Redacción el 16 de febrero de 2018

(161) Se ha propuesto en este trabajo que en esos casos se emita notificación solicitando que se subsane la solicitud donde se plantea la recusación con el fin de que se concrete la/s causa/s concreta/s alegada/s, con base en el artículo 68 de la LPACAP.

(162) Tal y como se ha argumentado en el presente trabajo, ante la diversidad de sentencias, no podemos negar la falta de consenso jurisprudencial; ahora bien, en cualquier caso, defendemos la obligación de tramitación de la denuncia, relacionando los artículos 34 de la LPS y 21 de la LPACAP.

(163) Recordemos que, tal y como se ha analizado en el epígrafe II.2 del presente artículo, no sólo podrán ser responsables las personas físicas y jurídicas, sino también los grupos de afectados, las uniones y entidades sin personalidad jurídica y los patrimonios independientes o autónomos, siempre que se les reconozca capacidad de obrar por parte de una ley (art. 28 LRJSP).

(164) En el sentido de varias acciones/omisiones que infrinjan el mismo o semejantes preceptos administrativos en ejecución de plan preconcebido o aprovechando idéntica ocasión (art. 29.6 LRJSP).

(165) Art. 62.4 LPACAP.

(166) Art. 85 LPACAP, con las consiguientes reducciones acumulables de, al menos, el $20 \%$ sobre el importe de la sanción propuesta. 
LABURPENA: Administrazio Publikoen Administrazio-prozedura Erkidearen 39/2015 eta Sektore Publikoaren Araubide Juridikoaren 40/2015 Legeak duela urte bat baino gehiago indarrean sartu dira. Ondorioz, Administrazio Publikoen lankidegoak bi arau horiek praktikara eramateko aukera izan du eta, horregatik, badirudi momentu egokia heldu dela analisi kritikoa egiteko. Hain zuzen, lan honen helburua zehapen-prozedura da (printzipioak, izapideak, ...); baina, bereziki, balizko aldaketak, prozeduraren lege berri horiek indarrean sartu eta gero. Halaber, saiatuko gara ikuspuntu kritikoak eta irteera posibleak ematen, oraindik aplikagarriak diren epai-erabakiak behin aztertuta.

GAKO HITZAK: Zehapen-prozedura. Administrazio-prozedura. Printzipioak.

RESUMEN: Tras haber transcurrido más de un año desde la entrada en vigor de las Leyes 39/2015 de Procedimiento Administrativo Común de las Administraciones Públicas y 40/2015 de Régimen Jurídico del Sector Público, el personal de las Administraciones Públicas hemos tenido ocasión de poner en aplicación ambas normas $y$, por ello, parece que ha llegado un momento óptimo para realizar un análisis crítico. En concreto, es objeto de este trabajo el procedimiento sancionador (principios, trámites,...), destacando posibles cambios tras la entrada en vigor de estas nuevas leyes de procedimiento, pero intentando aportar un punto de vista crítico y posibles soluciones a la vista de pronunciamientos jurisprudenciales que siguen resultando aplicables.

PALABRAS CLAVE: Procedimiento sancionador. Procedimiento administrativo. Principios.

ABSTRACT: After more than one year after the entry into force of the Laws $39 / 2015$ of the common administrative procedure of the Public Administrations and 40/2015 of legal regime of the public sector, the personnel of the Public Administrations have had opportunity to implement both standards and, therefore, it seems that there has been an optimal time to conduct a critical analysis. In particular, the sanctioning procedure (principles, processes,...) is the subject of this work and, specially, we want to analyze possible changes after the entry into force of these new procedural laws, but trying to provide a critical point of view and possible solutions in sight of jurisprudential pronouncements that continue to be applicable.

KEYWORDS: Disciplinary procedure. Administrative procedure. Principles. 